\title{
A Study on Obama's Optimistic Speech as Opposed to Trump's Disappointing Speech from a Systemic Functional Grammar Perspective
}

\author{
Marwa Adel Nasser
}

Department of English Language and Literature

Faculty of Women for Arts, Science and Education

Ain Shams University, Cairo, Egypt.

marwa.adel@women.asu.edu.eg

\section{Abstract}

The present study is a discourse analysis of Trump's and Obama's speeches on George Floyd's death. The study investigates two concepts, namely; identity and ideology as constructed through the linguistic choices of the two leaders. To explore the identity and ideology of the two leaders, the study adopts a combined framework of Halliday's (1994) Systemic Functional Grammar and Leech's (1985) Componential Analysis Theory. The collected data are examined from a lexico-grammatical and semantic analysis. The lexicogrammatical analysis, on the one hand, is governed by Halliday's SFG in which the ideational metafunction is explored through examining the transitivity system used by the two speakers. The semantic analysis, on the other hand, investigates the interpersonal meta-functions behind the two speeches through the six processes proposed by Halliday. The methodology involves a combination of both qualitative and quantitative methods through using corpus linguistic techniques. The data are processed using Sketch engine. Results show that the two leaders aroused contrasting views and strong feelings. Trump's speech, on the one hand, seems to be diappointing to many Americans and this is revealed through his ideology and thoughts that are detected from the analysis of the interpersonal and ideational meta-functions found in his speech. Obama, on the other hand, seems to be a great public speaker and orator, and this view is supported by his ideology and belief that are revealed in his speech.

Keywords: discourse analysis, ideology, identity, Systemic Functional Grammar, political speeches 


\section{Introduction}

Fairclough (2006, p.62) regards language as "a social practice" and discourse as "a mode of action" in which people may act upon the world and upon each other, as well as "a mode of representation". Accordingly, discourse helps construct social relationships between people. It also contributes to the construction of systems of knowledge and belief. Therefore, it can be assumed that the construction of the ideology, belief and identity of the speaker can be determined by the analysis of one's speech. The present study examines the speeches of Obama and Trump as a mode of reaction to an unusual event in the history of America about the death of George Floyd. On 25th of May 2020, America was shaken by protests from different cities about Floyd's death. What strikes the attention is the attitude of Trump and Obama towards this issue which has been reflected through their speeches. The study examines the language used in both speeches in order to draw a picture of the identity of the speakers through constructing their ideologies. This is done by analyzing the language used by both leaders using Halliday's (1994) Systemic Functional Grammar and Leech's (1985) Theory. Hence, the data are examined from a grammar-based and semantic-based analyses.

\section{Statement of the Study}

Through surveying the related literature, it has been evident that there seems to be no study that has conducted the task of analyzing the speeches delivered by Trump and Obama on the death of George Floyd, taking into consideration that this event is a recent issue.

\section{Objectives of the Study}

The current work has the following objectives:

a- Revealing the main intended ideologies found in the speeches of the two leaders.

b- Revealing the social identities of the two leaders.

c- Uncovering the lexical structures adopted by Trump and Obama.

d- Examining the semantic macrostructures in both speeches. 


\section{Research Questions}

The study intends to answer the following questions:

1- How are Trump's social identity and ideology represented ideationally and interpersonally in his speech?

2- How are Obama's social identity and ideology represented ideationally and interpersonally in his speech?

3- How far is Trump's identity and ideologies similar to or different from Obama's?

4- What are the dominating connotative and denotative nouns in the speeches of both leaders?

5- What do they indicate about the identity and ideology of the two leaders?

\section{Review of the Literature}

Before reviewing the related studies, it is important first to define some important concepts to the study.

\section{i. Discourse}

Linguists use many terms to refer to discourse. Some refer to it as language use, parole or performance. According to Fairclough (2006, p. 62), discourse refers to spoken or written language use. Baker (2006, p.5) defines discourse differently for he refers to discourse as " a system of statements which constructs an object". This definition is further classified by Burr (1995, p.48) as:

a set of meanings, metaphors, representations, images, stories, statements and so on that in some way together produce a particular version of events. Surrounding any one object, event, person, etc., there may be a variety of different discourses, each with a different story to tell about the world, a different way of representing it to the world (p.48).

\section{ii. Discourse Analysis}

Discourse analysis is the study of language in use. Language can be studied by various approaches; linguistics, sociolinguistics, pragmatics, and discourse analysis, etc. Language is essential in one's life as it performs many functions. It allows people to communicate with each other, to inform, to give, and get information. However, these are not the only functions of language, as it also 
allows people to 'do' things. This is what Gee (2010, p.2) asserts as he declares that "saying things in language never goes without also doing things and being things". He adds that language "allows us to engage in actions and activities. We promise things, we open committee meetings, we propose to our lovers, we argue over politics, and we "talk to God" (pray)" (p.2). Moreover, it allows people to be things. According to Gee (2010), language "allows us to take on different socially significant identities". In addition, "in language, there are important connections among saying (informing), doing (action), and being (identity)" (p.2). Gee (2011) explains that when he talks about "being things" he uses the word "identity" in a special way to mean "different ways of being in the world at different times and places for different purposes" (p. 3). Therefore, it can be said that language-inuse is about saying, doing, and being. Gee (2011) states that any full description of any use of language would have to deal with 'politics'. This is because language itself is political. It gains its meaning from the practice it is part of and enacts (pp. 8-10).

\section{iii. Ideology and Identity}

Ideology and identity are two central aspects of critical discourse analysis that are also driving forces of the present study. Taking first the concept of ideology, it has been defined as "a set of beliefs, or attitudes shared by members of a particular social group" (Bloor and Bloor 2007, p. 10). Furthermore, this definition was defined, more specifically, by Mesthrie (2010, p. 320) who states that ideology not only comprises a set of beliefs, but also "speech and cultural practices that operate to the advantage of a particular social group". According to Van Dijk (2006), the concept of ideology relies on four aspects: ideology as a system of belief; as a constituent of the identity of a group; its dominating force; and its stability. It is to be noted that ideology plays a fundamental role in the construction of one's identity.

Concerning the concept 'identity', Benwell and Stokoe (2006, p.21) point out that the term 'identity' includes numerous synonyms such as 'self', 'selfhood', 'position', role' personality, 'category', 'person formulation', 'person description', 'subjectivity', 'subject', 'agent', 'subject position' and 'persona'. There is no consensus among scholars about these terms and their relationship to different theories or traditions. Therefore, no special distinction between terms is Journal of Scientific Research in Arts (Language \& Literature) 5 (2021) 
mentioned here, as these terms are used interchangeably. In the present study, the term 'identity' refers to the way identities are construed and their significances in shaping the image of Obama and Trump as reflected during Floyd's death.

Regarding the related studies, it is found that there are a number of studies that examined political issues involving Trump and Obama. Tinshe (2019) examined the ideology behind Obama and Trump's political speeches about immigration as well as its relevance to the political discourse and social context in America. The study adopted Fairclough's three-dimensional framework. Seen from the political discourse, the speeches showed perceived superiority that the presidents have over immigrants. In addition, from the social perspective, it dehumanizes and reduces the identity of immigrants. Another study by Nguyen (2018), presented a comparative analysis on metaphoric strategies in presidential inaugurals of Obama and Trump through adopting conceptual metaphor theory and blending theory. The findings showed that metaphor can be a tool to reflect the politician's belief, orientation, idealism, and political targets. Suhadi and Baluqiah (2017) also explored the inaugural speech of Obama and Trump in 2016 as the target of a stylistic analysis. The study analyzed the oral communication by focusing on the content of speeches and how it was carried out as well. The findings showed that Obama's inaugural speech style is more communicative, evocative and its message is delivered orderly. However, Trump's style is more informal, but it was able to awaken audiences through huge topics, for instance American first, transferring power, nation, ... etc. As for Ricardo's study (2018), he analyzed the language forms used by Trump, and his predecessor Obama. Moreover, he discussed how their linguistic discourse influences their public image in the field of politics. The study was based on the analysis of three main focal points: the amount of words and length of sentences, the morphological composition and the use of pronouns in their speeches. The results showed some significant differences between the two presidents regarding the analyzed items and they seem to justify how they affect their public image. After this review, it seems that none of these studies treated George Floyd's death. Moreover, the study integrates both lexicogrammar analysis and semantic analysis in examining the speeches under investigation that is why it adopts two theoretical frameworks, namely; Halliday's SFG (1994) and Leech's Componential Analysis (1985) with the use of corpus linguistics (which is a very powerful tool that is not used in previous studies) 
bearing in mind two important concepts in critical discourse analysis; identity and ideology.

\section{Methodology}

The study is planned to address the research questions stated above from an SFG perspective and influenced by corpus linguistic methodology. The study applies a mixed-methods approach; qualitative and quantitative research methods for a better understanding of the purpose of the study. The qualitative research method creates broader understanding of the identity of the two leaders and highlights their ideologies reflected in their language use, whereas the quantitative research method focuses on numerical data taken from the speeches that can be transformed into statistical analysis. In addition, in order to remove bias, the study follows a corpus-assisted analysis to investigate the speeches under investigation. Using corpus linguistics helps in making some decisions that otherwise could have been biased. Therefore, the study uses sketch engine software program to achieve objective results.

\section{a. Data collection and Procedures}

The data for this study include: 1 . Obama's political speech to the protesters (25/05/2020), retrieved from the website https://www.elle.com/culture/careerpolitics/a32759738/president-obama-george-floyd-racism-police-brutality-townhall-quotes/ and 2. Trump's speech (01/06/ 2020) https://edition.cnn.com/2020/06/01/politics/read-trumps-rose-gardenremarks/index.html.

Each speech was saved in a file named by the name of the speaker. The files were uploaded on Sketch Engine tool for calculating and providing the statistics of the two speeches. The data went through three phases. The analysis, first, started by a quantitative analysis revealing the corpus statistics including the numbers of words, tokens, sentences in each speech, then, followed by both a qualitative interpretation of those statistics in the light of the theoretical framework of the study. The second phase focuses on two metafunctions to highlight the ideologies and to portray the social identity of both leaders through language use. The interpersonal metafunction focuses on the frequencies and significances of three 
features; mood, modality and pronoun system. Then, The ideational metafunction focuses on the transitivity analysis through Halliday's six processes. Finally, the third phase is devoted to the semantic analysis of the five most frequent nouns in each speech through giving their connotative and denotative meanings.

\section{b. Corpus Tools for the Analysis of Discourse}

According to Baker (2006), corpus-based techniques have been adopted in studies in an attempt to analyze differences in language usage based on identity (p.6). Using corpus-based approach helps to reduce researcher bias. The quantitative method is used to demonstrate the corpus statistic analysis including the numbers of words, tokens, sentences in each speech, whereas the qualitative analysis adopts the keyword function in order to provide information regarding the semantic environment in which significant lexical items of interest occur. The study analyzes both Obama's and Trump's speeches, using two main tools; word frequencies and concordances. These tools are employed to identify discourse patterns in both speeches.

It is to be noted that it is possible to carry out corpus-based analyses on much smaller amounts of data as Stubbs (1996) stated. Accordingly, this study works on a small amount of data as the corpora include only two political speeches, one for Trump and the other for Obama. It is expected to find results that could help in the purpose of the study. Three corpus tools are adopted in this study, namely; frequency, keyness and concordance.

\section{Theoretical Framework}

\section{i. Halliday’s (1994) Systemic Functional Grammar}

Halliday's (1980) approach is built on previous works of some influential linguists such as Bronislaw Malinowski and J.R. Firth. SFL approach is widely used in discourse analysis that is why it is adopted in this study to examine how the language is used in the speeches under investigation. Halliday (1994, p.15) points out that SFL interprets language as a network of or interrelated sets of options for systems, making meaning. Halliday and Hasan (1989) point out that "the concept of function is synonymous with that of use" (p.17). Accordingly, function is interpreted as a fundamental property of language. 
Based on this view, all languages are organized around two main kinds of meaning as mentioned by Halliday, namely; the 'ideational' and the 'interpersonal'. These components are referred to as 'meta-functions'.

\section{a. Stratification}

Language is a complex semiotic system involving various levels; the sound system (phonology), the writing system (orthography or graphology), and the wording system (grammar and semantics). According to Halliday and Hasan (1987), grammar and vocabulary are grouped under the name (lexicogrammar). These levels are grouped into two stratal planes, namely; the content plane and the expression plane. As for content, it is mapped directly onto expression (vocal or gestural). Content gradually splits into semantics and lexicogrammar, and expression gradually splits into phonology and phonetics. The study focuses on the generalized meanings or meta-functions determined from the speeches of the two speakers. The approach focuses on text analysis as a mode of action.

\section{Lexicogrammar}

Halliday (1961, p.251) points out that the units of the grammar form a hierarchy (or rank) that is classified from the largest unit to the smallest unit. The largest unit represents the clause, while the smallest one represents the word. Under each unit, there consist several numbers of units. The following figure represents the units under the clause. 


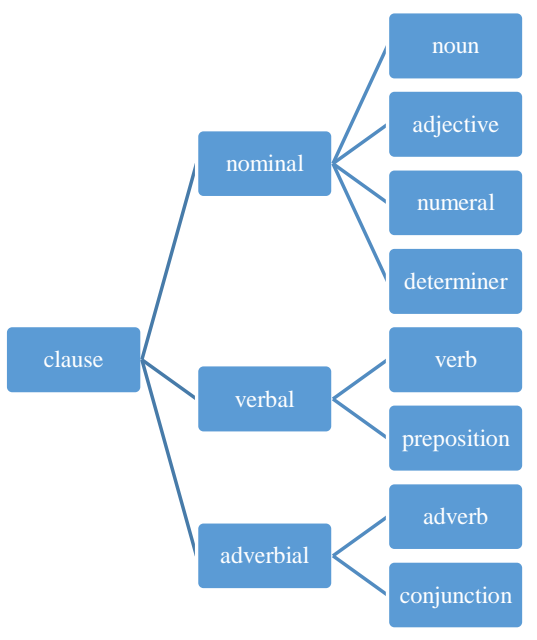

Fig 1: word classes in SFL (adopted from Halliday and Matthiessen (2014, p.75).

Halliday and Matthiessen (2014) classify the clause into nominal group, verbal group, and adverbial group. Under each group, they classify words into different classes (nouns, adjectives, numerals and determiners, verbs and prepositions, adverbs and conjunctions). These units are essential in the SFL as comparing these units can reveal a variety of outcomes. Examining the lexis and grammar in this study aims to spot the differences between the two leaders to construct their identities as reflected through their ideologies. The following section presents the different meta-functions proposed by Halliday (1994).

\section{Discourse-Semantics}

Above the level of lexis and grammar, clause is considered as it is the unit in which meanings of different kinds are combined (Halliday, 1994, p.37). SFL model assumes that three kinds of meaning are generated from human language; the ideational (clause as representation) and the interpersonal (clause as exchange) and textual meta-function (clause as message) (Halliday, 1994, p.39).

\section{A- The Ideational Meta-function}

The ideational or experiential meta-function means representing the world, either the external world (such as things, events, qualities, etc.) or the internal world (such as thoughts, beliefs, feelings, etc.) as stated by Halliday and Matthiessen (2014, p.91). They believe that "language provides a theory of human experience" 
and they assume that "certain of the resources of the lexicogrammar of every language are dedicated to that function" (p.29). Its main grammatical system is classified as Transitivity (Halliday and Matthiessen, 2014, p.63) which includes three components: processes, participants, and circumstances (Halliday, 1994, p.179). The participants belong to the nominal group and the circumstances belong to an adverbial group or a prepositional group, whereas the processes belong to the verbal group (2014, p.176).

There are six processes mentioned by Halliday (1994), they are; material, behavioural, mental, verbal, relational, and existential. Each process is characterized by a different kind of participants and different category meanings. Material processes are those which involve physical actions and concrete happenings and doings. They will have two participants the doer of the action known as the 'Actor' and the person or thing that the action is done to, which is known as 'Goal'. Mental processes are processes of sense. They are divided into four types perceptive, emotion, cognition, and desire. Mental processes include the 'Sensor', the one that is feeling (the participant). Verbal Processes involve the communication between two participants: the Sayer and the Receiver or addressee and it involves the message of content, the verbiage. Relational processes are processes of being. There are two types of relational processes: 'attributive relational processes' and 'identifying relational processes'. Behavioural process is the process of physiological and psychological behaviour such as smile, cry, laugh, etc. Usually, the verbs of this process are intransitive verbs and it has only a participant, namely the behaver. Existential Process refers to something that exists or happens. The verb used in this process is verb 'to be' or any other verb that indicates occurrence or existence (e.g., exist), while the subject is 'there'.

\section{B- The Interpersonal Meta-function}

It deals with the use of language between the speaker(s) and the addressee(s). According to Halliday (1994, p.68), it is used to determine the role played by the speaker in the speech situation and the relationship with other partners. This relation is of the goal either to influence their behavior or to show a viewpoint or to change something (clause as message). The principle grammatical systems involved are; Mood and Modality (Matthiessen \& Halliday 1994, p.68), in addition to, Pronoun system. 


\section{I- Mood}

Halliday (1994) states:

the grammatical category that is characteristically used to exchange information is the indicative; within the category of indicative, the characteristic expression of a statement is the declarative, that of a question is the interrogative; and within the category of interrogative there is a further distinction between yes-no interrogative, for polar questions, and $\mathrm{WH}$ interrogative, for content questions (p.74).

Therefore, it can be said that mood includes two types of sentences; indicative and interrogative. Each of which has its significance to the analysis of any text.

\section{II- Modality}

Modality is related to the expression of the speaker's attitude about what they are saying (Webster, 2003). By Modality, Halliday (1994, p.75) means the speaker's judgment of the probabilities, or the obligations, involved in what he is saying. Modality can express different senses. It can express certainty, possibility, willingness, obligation, necessity, and ability through the use of modal verbs and expressions. Speakers usually have different opinions about the same thing depending on the value of the modal verb whether it is high, median, or low.

\section{III- Pronoun System}

Examining the interpersonal meaning of the pronoun in different situations is significant and can have distinctive indications. Halliday (2002, p.191) divides the pronoun system into personal pronouns and possessive pronouns which are used to show the interpersonal meaning of any language as well as they are used to strengthen the speaker-hearer relation. Personal pronoun is important especially to the study of political discourse for they reveal the identity of the speaker, whom he identifies himself with. Pronouns are divided into three categories; first-person group (e.g. I, me, we, us), second-person group (e.g., you), and third-person group (e.g., she, he, it, they, them, her, him).

A third meta-function which is found in Halliday's model is textual metafunction, however, it is not mentioned here as the study is restricted to the first two meta-functions only; interpersonal and ideational. 


\section{ii. Componential Semantic Approach}

The choice of a word usually carries different implications and especially if this choice is repeated frequently in one's speech. Therefore, the study adopts Leech's (1985) Componential Semantic Approach to explore the different implications behind the lexical choices of the two speakers.

\section{a. Componential analysis of meaning}

Goddard and Wierzbicka (2014, p.3) assert that words are "the essential props in social life". Through words, people can know what other people think or what they want to say to others. The meanings of words are associated with other words in the language. Being in the same semantic domain, words can show common and distinguished features. Componential analysis of meaning can be a valuable tool in analyzing the word into its minimal distinctive features especially when defining the meaning of a lexical item. According to Finegan (2004, pp. 181-182), meaning can be classified into three types, namely; linguistic, social, and affective meaning. As for the linguistic meaning, it includes both sense and reference. To define the meaning of a word or a sentence, one can refer to the actual person, object, abstract notion, event, or state to which the word or sentence refers. The second type, social meaning, refers to what people depend on when they try to determine particular social characteristics of speakers and situations from the character of the language being used. The third type is the affective meaning, which refers to the emotional connotation that is attached to words and utterances. The current study focuses on the linguistic meaning which expresses the denotative meaning of words, in addition to, the affective meaning which refers to the connotative meaning of words.

\section{Data Analysis}

The following section is divided into three parts. The first part deals with the corpus analysis, while the second deals with the meta-functions analysis in the speeches of the two speakers and the third part deals with the semantic analysis in the light of the componential semantic analysis.

\section{Trump and Obama's Speeches Corpus Analysis}


A corpus-driven percentage is offered for the grammatical and lexical choices in both Trump's and Obama's political speeches. The following table shows the number of words, tokens, sentences and documents in both speeches.

Table (1). Trump's and Obama's speeches corpus analysis

\begin{tabular}{|l|l|l|l|}
\hline & Tokens & Words & Sentences \\
\hline $\begin{array}{l}\text { Trump's } \\
\text { speech }\end{array}$ & 917 & 799 & 55 \\
\hline $\begin{array}{l}\text { Obama's } \\
\text { speech }\end{array}$ & 2225 & 1956 & 85 \\
\hline
\end{tabular}

The analysis shows that Trump used 971 tokens and 799 words in his speech forming 55 sentences, while Obama used 2225 tokens and 1956 words forming 85 sentences only. It was not surprising to find out that Trump produces less utterances and less word frequency than Obama. This can be attributed to Trump's personality that was known for being speaking articulately, who usually uses simple word choices, and inserted dependent clauses into his sentences. He uses simpler speech patterns, few polysyllabic words, and noticeably more fillers such as 'uh' and 'I mean'. On the contrary, Obama has his own way of talking. He understands the power of language and he chooses his words carefully to spread his worldview. He relies on simple language to explain complex ideas.

\section{A. Meta-functions Analysis}

The study tackles two meta-functions in an attempt to answer the research questions proposed in the study.

\section{Meta-function analysis of Trump's and Obama's speeches}

\section{Interpersonal meta-function}

To figure out the message behind the speech, an interpersonal analysis is carried out in this study based on three systems, they are; Mood, Modality and Pronoun system. 
A Study on Obama's Optimistic Speech as Opposed to Trump's Disappointing Speech from a Systemic Functional Grammar Perspective

\section{i. Mood analysis in Trump's and Obama's speech}

A mood analysis of Trump's and Obama's speeches is provided. Their indicative and imperative frequencies are displayed to come up with the difference between the two leaders.

Table (2) Mood in Trump's speech

\begin{tabular}{|c|c|c|c|}
\hline \multicolumn{3}{|c|}{ Trump } \\
\hline \multirow{2}{*}{ Mood } & \multicolumn{2}{|c|}{ Indicative } & \multirow{2}{*}{ Imperative } \\
\cline { 2 - 4 } & Declarative & Interrogative & - \\
\hline Frequency & 255 & - & $0 \%$ \\
\hline Percentage & $100 \%$ & $0 \%$ & \\
\hline Total & 255 & & \\
\hline
\end{tabular}

Table (3) Mood in Obama's speech

\begin{tabular}{|c|c|c|c|}
\hline \multicolumn{3}{|c|}{ Obama } \\
\hline \multirow{2}{*}{ Mood } & \multicolumn{2}{|c|}{ Indicative } & \multirow{2}{*}{ Imperative } \\
\cline { 2 - 3 } & Declarative & Interrogative & 4 \\
\hline Frequency & 79 & 2 & $5 \%$ \\
\hline Percentage & $93 \%$ & $2 \%$ & \\
\hline Total & \multicolumn{3}{|c}{} \\
\hline
\end{tabular}

The analysis demonstrates that both leaders show a very high frequency of declaratives which represents their thoughts. Obama uses different moods; declarative, interrogative and imperative mood, whereas Trump only uses only declarative mood. The declarative sentences in Trump's speech represent $100 \%$ of the total number of sentences in the speech and they show him as decisive about Journal of Scientific Research in Arts (Language \& Literature) 5 (2021) 
the fact that he is the president of law. Instead of showing his intention to solve the main grievance of the protestors, he declares himself as the defender of order. As for Obama, the declarative sentences represent $79 \%$, while the interrogative sentences represent only $2 \%$, and the imperative sentences represent $5 \%$ of the total number of sentences in his speech. Using different varieties of mood indicates that Obama wants the audience to interact with him, sometimes by asking rhetorical questions, thus inviting them to think however he does not call for any overt response for he answers the questions after imposing them. Sometimes he uses imperative mood in order to let the protesters take part in overcoming this crisis. This reflects Obama's identity as evocative and assertive. It seems that Obama happened to be the right person in American politics especially controversial issues. As Americans continue to protest, president Trump threatened to end protests with military declaring himself the "president of law and order", while the former president Obama stepped in as he felt compelled to intervene. He never wants to be seen as speaking for all black Americans. However, he was too worried about the condition of the country to stay silent about George Floyd's death and the protests that have followed. Obama offered words of hope in contrast to Trump's division as he said: "Your lives matter". Obama spoke directly to young men and women of color. He felt optimistic as he felt that America is going to be better.

\section{a. Indicative mood examples as used by Trump}

All the examples are declarative sentences and they are analyzed in the form of tables.

Example no.1: I am your President of law and order.

This sentence can be represented by the following table:

Table (4) Example no.1 Declarative Mood Analysis

\begin{tabular}{|l|l|l|}
\hline I & Am & $\begin{array}{l}\text { your President of law and } \\
\text { order }\end{array}$ \\
\hline Subject & $\begin{array}{l}\text { Finite } \\
\text { (present) }\end{array}$ & Complement \\
\hline
\end{tabular}


A Study on Obama's Optimistic Speech as Opposed to Trump's Disappointing Speech from a Systemic Functional Grammar Perspective

\begin{tabular}{|l|l|}
\hline $\begin{array}{l}\text { Mood } \\
\text { (Declarative) }\end{array}$ & Residue \\
\hline
\end{tabular}

Example no.2: These are not acts of peaceful protest.

This sentence can be represented by the following table:

Table (5) Example no. 2 Declarative Mood Analysis

\begin{tabular}{|l|l|l|}
\hline These & are not & acts of peaceful protest \\
\hline Subject & $\begin{array}{l}\text { Finite } \\
\text { (present) }\end{array}$ & Complement \\
\hline $\begin{array}{l}\text { Mood } \\
\text { (Declarative) }\end{array}$ & & Residue \\
\hline
\end{tabular}

Example no.2: These are not acts of peaceful protest.

This sentence can be represented by the following table:

Table (6) Example no. 2 Declarative Mood Analysis

\begin{tabular}{|l|l|l|}
\hline These & are not & acts of peaceful protest \\
\hline Subject & $\begin{array}{l}\text { Finite } \\
\text { (present) }\end{array}$ & Complement \\
\hline $\begin{array}{l}\text { Mood } \\
\text { (Declarative) }\end{array}$ & & Residue \\
\hline
\end{tabular}

\section{b. Indicative mood examples as used by Obama}

The examples belong to declarative sentences as well as interrogative sentences.

\section{i- $\quad$ Declarative sentences}

Example no.1: And it makes me feel optimistic.

This sentence can be represented by the following table: 
A Study on Obama's Optimistic Speech as Opposed to Trump's Disappointing Speech from a Systemic Functional Grammar Perspective

Table (7) Example no.1 Declarative Mood Analysis

\begin{tabular}{|l|l|l|l|}
\hline I & Makes & Me & $\begin{array}{l}\text { feel } \\
\text { optimistic }\end{array}$ \\
\hline Subject & $\begin{array}{l}\text { Finite } \\
\text { (present) }\end{array}$ & Complement & \\
\hline $\begin{array}{l}\text { Mood } \\
\text { (Declarative) }\end{array}$ & & Residue \\
\hline
\end{tabular}

Example no. 2: I want you to know that your lives matter

This sentence can be represented by the following table:

Table (8) Example no. 2 Declarative Mood Analysis

\begin{tabular}{|l|l|l|l|}
\hline I & Want & You & $\begin{array}{l}\text { to know that } \\
\text { your lives matter }\end{array}$ \\
\hline Subject & $\begin{array}{l}\text { Finite } \\
\text { (present) }\end{array}$ & Complement \\
\hline $\begin{array}{l}\text { Mood } \\
\text { (Declarative) }\end{array}$ & & \multicolumn{2}{|c|}{ Residue } \\
\hline
\end{tabular}

\section{ii- Interrogative sentences}

It is found that Obama's speech imposes two direct questions to the protests. They are as follows:

Example no.1: What can we do?

This interrogative sentence can be represented by the following table:

Table (9) Example no. 1 Interrogative Mood Analysis

\begin{tabular}{|l|l|l|l|}
\hline What & Can & We & do? \\
\hline Complement & Finite (present) & Subject & Complement \\
\hline Residue & \multicolumn{3}{|c|}{ Mood (Interrogative) } \\
\hline
\end{tabular}


Example no.2: What are the specific steps you can take?

This interrogative sentence can be represented by the following table:

Table (10 ) Example no. 2 Interrogative Mood Analysis

\begin{tabular}{|l|l|l|l|l|}
\hline what & Are & $\begin{array}{l}\text { the specific } \\
\text { steps }\end{array}$ & $\begin{array}{l}\text { You } \\
\text { take? }\end{array}$ \\
\hline Complement & $\begin{array}{l}\text { Finite } \\
\text { (present) }\end{array}$ & Complement & Subject & \\
\hline Residue & \multicolumn{3}{|c|}{ Mood (Interrogative) } \\
\hline
\end{tabular}

\section{Imperative Mood examples:}

Example no.1: Please know that Michelle and I and the nation grieve with you.

This imperative sentence can be represented by the following table:

Table (11) Example no. 2 Imperative Mood Analysis

\begin{tabular}{|c|c|c|c|}
\hline Please & Know & $\begin{array}{l}\text { that Michelle and I } \\
\text { and the nation }\end{array}$ & grieve with you \\
\hline \multicolumn{2}{|c|}{ Finite (present) } & Complement & \\
\hline \multicolumn{2}{|c|}{$\begin{array}{l}\text { Mood } \\
\text { (Imperative) }\end{array}$} & \multicolumn{2}{|c|}{ Mood (Interrogative) } \\
\hline
\end{tabular}

Example no.2: get working with that because it can make a difference This imperative sentence can be represented by the following table:

Table (12) Example no. 2 Imperative Mood Analysis

\begin{tabular}{|l|l|l|l|}
\hline Get & working with & That & $\begin{array}{l}\text { because it can } \\
\text { make a } \\
\text { difference }\end{array}$ \\
\hline Finite (present) & Complement \\
\hline
\end{tabular}




\begin{tabular}{|l|c|}
\hline $\begin{array}{l}\text { Mood } \\
\text { (Imperative) }\end{array}$ & Mood (Interrogative) \\
\hline
\end{tabular}

The examples above show the extensive use of declarative sentences in Trump's speech which reveals that Trump seems to be informative. He began to talk about Floyd, and how he died. Then, he described how all Americans were rightly sickened and revolted by the brutal death of George Floyd. He asserted that his administration "is fully committed that for George and his family justice will be served. He will not have died in vain." For the rest of Trump's speech, he did not mention or commit to solve the main grievance of the protesters. Instead, he declared himself as the defender of order who will fight to protect them for he is the president of law and order. At the end, he firmly stated that he "will deploy the United States military and quickly solve the problem for them". It is obviously seen from Trump's speech that he was trying to draw the protesters' attention that he is the president of America and his ideology was clear for he will not allow any disorder or violence to happen in his country and that's why his speech was full of declarative sentences.

On the contrary, the indicative mood as used by Obama shows how Obama was so worried about the condition of the country to stay silent about George Floyd's death and the protests that have followed. His use of the imperative mood was directed to the protesters for he wanted them to know that he and Michelle grieve with them, and they hold them in their prayers. Then, he asked them to learn and make mistakes and live a life of joy without having to worry about what's going to happen when they walk to the store, or go for a jog, etc. He, then, paid tribute to police officers and urged them to reform. He also proposed two questions to the protests asking them what they can do and what the specific steps that they take are. By these two questions he was inviting the protests to share their thoughts and feel as one unity and try to solve the problem.

\section{ii. Modality Analysis}

Modality is used by the speaker to inform the listener about his/her personal thoughts through his speech. It is also used to express feelings in a certain circumstance. Moreover, it is used to show the speaker's commitment toward the 
A Study on Obama's Optimistic Speech as Opposed to Trump's Disappointing Speech from a Systemic Functional Grammar Perspective

plans he/she offers. The following sections deal with the results of modality analysis as found in Trump and Obama's speeches.

\section{a. Modality Analysis in Trump's and Obama's Speeches}

Modal verbs can have different semantic connotations and communicative functions. The following table shows the frequency of the different modal operators found in Trump's and Obama's speeches.

Table (13 ) Frequency of modal operators in Trump's and Obama's speeches

\begin{tabular}{|l|l|l|l|l|l|}
\hline \multicolumn{3}{|c|}{ Trump } & \multicolumn{3}{|c|}{ Obama } \\
\hline Modal & Frequency & Percentage & Modal & Frequency & Percentage \\
\hline Will & 15 & $71 \%$ & Can & 8 & $30 \%$ \\
\hline Necessary & 2 & $9 \%$ & Should & 3 & $10 \%$ \\
\hline Need & 1 & $5 \%$ & Having to & 1 & $3 \%$ \\
\hline Must & 1 & $5 \%$ & Has to & 1 & $3 \%$ \\
\hline Always & 1 & $5 \%$ & Have to & 3 & $10 \%$ \\
\hline Can & 1 & $5 \%$ & Had to & 1 & $3 \%$ \\
\hline Total & 21 & $100 \%$ & Could & 1 & $3 \%$ \\
\hline & & & Need & 2 & $6 \%$ \\
\hline & & & Would & 3 & $10 \%$ \\
\hline & & & Think & 1 & $3 \%$ \\
\hline & & & Sometimes & 1 & $3 \%$ \\
\hline & & & May & 1 & $3 \%$ \\
\hline
\end{tabular}




\begin{tabular}{|l|l|l|l|l|l|}
\hline & & & Often & 3 & $10 \%$ \\
\hline & & & Total & 30 & $100 \%$ \\
\hline
\end{tabular}

This table shows that Trump used 21 different modal operators in his speech, whereas Obama used 31 different modal operators in his speech. Both Trump and Obama use modal operators to express their feelings towards this crisis facing America and towards the attitude of the protesters. Trump wants to show his commitment to the propositions he plans to do, and Obama wants to show his opinion about this issue. Moreover, the table shows that the modal verb 'will' is the most frequently used modal in Trump's speech with percentage $71 \%$ followed by 'necessary' which represents $9 \%$, while the rest of modal operators are only appeared once with percentage $5 \%$ for each. Unlike, the modal verb 'can' which is the most frequently used modal in Obama's speech with percentage $30 \%$ followed by 'should, would, often, have to' which represent $10 \%$ for each, then the modal operator 'need' occurred twice with percentage $6 \%$ and finally come the rest of modal operators such as 'having to, has to, had to, could, think, sometimes, may, and maybe' each occurred once with percentage $3 \%$ each.

These findings show that Trump's few modal operators, on the one hand, indicate his negative attitude towards the protests and shows again his assertiveness of being the president of America who will never allow any violence or chaos to happen in the country. On the other hand, the variety of use of modal operators in Obama's speech, indicate his attitude of belonging to America and this is expressed by his use of the question 'what can we do?' It also indicates his optimism towards the future and how to avoid such accidents in the future.

The following table shows the distribution of the modal verbs either into modalization or modulation as divided by Halliday (1994).

Table (14 ) Distribution of Modals in Trump's speech

\begin{tabular}{|l|l|}
\hline \multicolumn{2}{|c|}{ Trump } \\
\hline Modalization & Modulation \\
\hline
\end{tabular}


A Study on Obama's Optimistic Speech as Opposed to Trump's Disappointing Speech from a Systemic Functional Grammar Perspective

\begin{tabular}{|l|l|l|l|}
\hline Probability & Usuality & Obligation & Inclination \\
\hline Can & Always & $\begin{array}{l}\text { Must, need, } \\
\text { necessary }\end{array}$ & Will \\
\hline 1 & 1 & 4 & 15 \\
\hline \multicolumn{2}{|c|}{2} & \multicolumn{2}{|c|}{19} \\
\hline Percentage & $10 \%$ & $90 \%$ \\
\hline
\end{tabular}

Table (15) Distribution of Modals in Obama's speech

\begin{tabular}{|l|l|l|l|}
\hline \multicolumn{3}{|c|}{ Obama } \\
\hline Probability & Usuality & Obligation & Inclination \\
\hline $\begin{array}{l}\text { can, could, may, } \\
\text { maybe, think }\end{array}$ & sometimes, often & $\begin{array}{l}\text { have to, has to, } \\
\text { had to, having to, } \\
\text { need, should }\end{array}$ & Would \\
\hline 12 & 4 & 11 & 3 \\
\hline & 18 & \multicolumn{2}{|c|}{$40 \%$} \\
\hline Percentage & $60 \%$ & \multicolumn{2}{|c|}{40} \\
\hline
\end{tabular}

The distribution of modals demonstrates that $90 \%$ of the modal operators used by Trump belong to modulation and $10 \%$ belong to modalization. These percentages show that Trump seemed to be firm, strong and certain about his decisions. That's why he repeated 'will' 15 times and used words that show obligation such as must, need and necessary. As for Obama, 60\% of the modal operators used by Obama 
belong to modalization and $40 \%$ belong to modulation. These percentages show that Obama showed sympathy for Floyd that's why modal operators that belong to modalization are more than those belong to modulation. Words that show probability and usuality are more than words showing obligation and inclination. This can be attributed to the fact that Obama is no longer in a position to change the current situation. He is a former president, that is why he couldn't give commitments, he is just expressing feelings of solidarity with the protests and trying to give solutions to the issue.

Each type of modal verbs has a certain value; therefore, the following table demonstrates the value of the existed modal verbs in Trump and Obama's speeches. By value, Halliday (1994) means variability of modal verbs. The values are classified into high, median and low.

Table (16) Values of Modal operators in Trump's speech

\begin{tabular}{|c|c|c|c|}
\hline \multicolumn{3}{|c|}{ Trump } \\
\hline Value & High & Median & Low \\
\hline $\begin{array}{c}\text { Modal } \\
\text { operators }\end{array}$ & Must, need, always & Will, necessary & can \\
\hline Frequency & 3 & 17 & 1 \\
\hline Percentage & $14 \%$ & $81 \%$ & $5 \%$ \\
\hline
\end{tabular}

Table (17) Values of Modal operators in Obama's speech

\begin{tabular}{|c|l|l|l|}
\hline \multicolumn{3}{|c|}{ Obama } \\
\hline Value & \multicolumn{1}{|c|}{ High } & \multicolumn{1}{c|}{ Median } & Low \\
\hline $\begin{array}{c}\text { Modal } \\
\text { operators }\end{array}$ & $\begin{array}{l}\text { have to, has to, had } \\
\text { to, having to, need, } \\
\text { should, }\end{array}$ & Would & $\begin{array}{l}\text { Can, could, may, } \\
\text { maybe, think, } \\
\text { sometimes, often }\end{array}$ \\
\hline
\end{tabular}


A Study on Obama's Optimistic Speech as Opposed to Trump's Disappointing Speech

from a Systemic Functional Grammar Perspective

\begin{tabular}{|c|c|c|c|}
\hline Frequency & 11 & 3 & 16 \\
\hline Percentage & $37 \%$ & $10 \%$ & $53 \%$ \\
\hline
\end{tabular}

The tables show that the highest value in Trump's speech is the median value with percentage $81 \%$, followed by the high value with $14 \%$ and finally the low value representing 5\%. Unlike Obama's speech in which the highest value is the low value with percentage $53 \%$, followed by the high value with $37 \%$ and finally the median value representing $10 \%$. Thus, Obama's high usage of low value modal operators shows his attitude and opinion about the truth of this issue, while Trump's high usage of median value shows his desire to show power to manage what is happening in America. Obama's low usage of median value in contrast to Trump's usage indicates his lack of power, and although his speech was so influencing, yet he does not have the authority to change the current situation. In addition, Trump's low usage of low value of modal operators reveals that his speech was not to present any solutions about the crisis, but only to demonstrate his power and control. The following are examples of each value in order to come up with some traits about each leader.

\section{Examples from Trump's speech}

\section{1- High value modal examples}

a- We must never give in to anger or hatred.

b- America need creation, not destruction.

\section{2- Median value modal examples}

a- Justice will be served.

b- I will fight to keep them safe

\section{3- $\quad$ Low value modal examples}

a- But we cannot allow the righteous prize and peaceful protests to be drowned out by an angry mob.

Examples from Obama's speech 


\section{1- High value modal examples}

a- $\quad$ To bring about real change, we both have to highlight a problem and make people in power uncomfortable, but we also have to translate that into practical.

b- $\quad$ And so I just had to say, thank you to them for helping to bring about this moment and just make sure that we now follow through.

\section{2- Median value modal examples}

a- What can we do? Number one, we know there are specific evidence based reforms that if we put in place today would build trust, save lives would not show an increase in crime.

\section{3- Low value modal examples}

a- $\quad$ We can monitor and make sure we're following up...

b- $\quad$ And so I hope that you also feel how hopeful, even as you may feel angry.

These examples support the view that Trump wants to show strong obligations towards resolving this crisis and also to show the necessities of the actions that should be taken to solve the problem. In addition, it shows Trump's prediction as he states that they will be able to succeed and in order to emphasize that he adds $100 \%$ for confirmation. As for high value modal verbs, they come in the second position after median value modal verbs. The High value modals in Trump's speech indicate a strong sense of obligation as he directs his speech to the protesters compelling them not to retain anger and hatred. Moreover, he assures that America needs creation not destruction. By stating "our country always wins" he guarantees victory for his country. The use of low value modal is accompanied by the occurrence of 'not', and as Kreidler (1998, pp.244-247) states that the negation after the modal verb may negate the content of the following proposition.

However, in Obama's speech, the high frequency of the low value modal verbs shows Obama's willingness of what they can hopefully do and what people can do. However, his use of the modal verb 'may' reveals his understanding of people's feelings of anger towards Floyd's death. The use of the different word forms of (have to) shows his optimistic remarks about the future and it 
demonstrates also the obligations that they have to do towards this crisis. The median value modal operators are used least and they indicate what Obama expected or thought to happen.

\section{Pronoun system}

The pronoun system is an important tool for highlighting the interpersonal role. The following sections show the pronoun system as used by Trump and Obama.

\section{First-person in Trump's and Obama's speech}

Table (18). The use of the 1st person pronoun by Trump and Obama

\begin{tabular}{|c|c|c|c|c|c|c|c|c|c|c|c|c|}
\hline \multicolumn{6}{|c|}{ Trump } & \multicolumn{7}{|c|}{ Obama } \\
\hline \multirow{2}{*}{$\begin{array}{l}\text { Personal } \\
\text { pronoun }\end{array}$} & & & & & & & & & & & & \\
\hline & - & 3 & 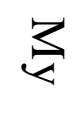 & $\mathcal{C}$ & $\sum_{0}$ & $\stackrel{-1}{\stackrel{0}{\Xi}}$ & - & 3 & 3 & $c_{\infty}$ & $\sum_{0}$ & $\overrightarrow{0}$ \\
\hline Frequenc & $\vec{A}$ & 1 & $\Delta$ & - & $\bar{\omega}$ & $\underset{N}{W}$ & $\stackrel{\mathcal{N}}{N}$ & 6 & $\theta$ & $A$ & $\tilde{u}$ & $\vec{I}$ \\
\hline
\end{tabular}

This table shows that Trump uses different several 1st person pronouns. The total number of first-person is 32 . There are 18 singular 1 st person pronouns, while the plural forms are 14. Thus, Trump uses more singular forms than the plural ones. This can indicate that Trump talks about himself more than embracing himself among people. In other words, it reveals how arrogant and egotistical Trump is as he may have self-confidence. As for Obama, there is an extensive use of 1st person pronouns whether singular or plural of total number 74 . The number of firstperson singular pronouns is 45 , whereas the number of plural pronouns is 29 . His use of singular 1st person pronoun indicates that he wants to convey his opinion. It can also indicate that the speech is subjective as it is a way to show his compassion with the protesters. Moreover, it gives a sense that Obama captures the moment. He is here and he has a relationship with the protesters. 
The following examples are taken from Trump's speech in support of the view about Trump's personality. All the examples reveal that Trump has all the power and everything is done by his will. Only one example shows Trump as a caring president when he calls the protesters as 'my fellow Americans'.

1- $\quad$ I will fight to keep them safe.

2- I will fight to protect you.

The following examples are quotes from Trump's speech in which he uses the personal pronoun 'we':

1- $\quad$ We will succeed $100 \%$

2- We must never give in to anger or hatred.

All the examples where Trump uses 'we' show that Trump is trying to send a message to the protesters that he is not alone, and he speaks in behalf of the administration and government, and this is also in a way to show that he and his administration is one unity and hence, he has all the power in his hands.

Supporting the view about Obama's personality, the following examples are quotes from his speech in which he uses the person pronoun 'I' in a different way from Trump.

1-I want you to know that you matter, I want you to know that your lives matter.

2-.....I want to be part of the solution..

The examples show Obama's commitment and personal involvement in the issue. Although both leaders use the first person singular, yet there is a clear difference in the use of the pronoun which reflects their different identities. The following examples are quotes from Obama's speech in which he uses the plural form of the first-person pronoun 'we'.

3- And so we're grateful for the vast majority of you protesters

4- To bring about real change, we both have to highlight a problem and make

'We' in Obama's speech gives a sense of institutional identity. Obama seems to speak as a representative of or on behalf of all the protesters. This is reinforced by 
the use of the possessive pronoun 'us'. He shares responsibility with them, and this is clearly perceived by his question 'what can we do?' He invited them to share their thoughts with him, and carry the responsibility to think about the future.

\section{Second-person in Trump's and Obama's speeches}

Table (19). The use of $2^{\text {nd }}$ person by Trump and Obama

\begin{tabular}{|c|c|c|c|c|c|c|}
\hline & \multicolumn{3}{|c|}{ Trump } & \multicolumn{3}{|c|}{ Obama } \\
\hline & \multicolumn{6}{|c|}{$2^{\text {nd }}$ person } \\
\hline $\begin{array}{l}\text { Personal } \\
\text { Pronoun }\end{array}$ & You & Your & Total & You & Your & Total \\
\hline Frequency & 5 & 4 & 9 & 28 & 7 & 35 \\
\hline
\end{tabular}

The table shows that Trump uses 'you' 5 times only and 'your' 4 times with a total number of 9 times using the second person, while Obama uses 'you' 28 times and 'your' 7 times with a total frequency 35 times. 'you' in this study is meant to address the protesters directly. The low frequency of using the personal pronoun 'you' by Trump shows he is unconcerned about them which is so disappointing to them. He speaks in a very generic way, not referring to anyone in particular. Another interpretation is that Trump is criticizing the protesters by his use of the pronoun 'you'. The use of 'you' by Obama indicates that he wants to engage the protesters with him that is why he uses it frequently. They are his main target and he is giving his speech to them to calm them down and to support them and to send them a message that he is part of them.

\section{Third-person in Trump's and Obama's speeches}

Table (20). The use of $3^{\text {rd }}$ person by Trump

\begin{tabular}{|c|c|c|c|c|c|c|}
\hline Personal & \multicolumn{6}{|c|}{ Trump } \\
\cline { 2 - 7 } Pronoun & They & He & Their & His & Them & Total \\
\hline Frequency & 1 & 1 & 4 & 1 & 2 & 9 \\
\hline
\end{tabular}

Table (21). The use of $3^{\text {rd }}$ person by Obama 
A Study on Obama's Optimistic Speech as Opposed to Trump's Disappointing Speech from a Systemic Functional Grammar Perspective

\begin{tabular}{|l|l|l|l|l|l|l|l|}
\hline & \multicolumn{7}{|c|}{ Obama } \\
\hline $\begin{array}{l}\text { Personal } \\
\text { Pronoun }\end{array}$ & They & He & Their & His & Them & Themselves & Total \\
\hline Frequency & 9 & 1 & 2 & - & 3 & 1 & 16 \\
\hline
\end{tabular}

The tables show that the least frequency is for the third person pronouns in Trump's speech. One striking finding is that the personal pronoun (he) referring to Floyd is mentioned only once when Trump stated that Floyd will not die in vain. This shows Trump's negligence of Floyd as a victim which is so disappointing to many Americans, and that his main concern is the protesters whom he wants to control so that no chaos could happen. As for Obama, most of the frequently used pronouns is 'they' which is used by Obama in a neutral context. It does not refer to the others. He does not speak of others in a negative or positive way. 'They' is used as a referent to different entities. This is clearly seen from the examples found in his speech:

1- They are the outcomes,.....

$2-\ldots$. they're the result of a long history of slavery

To sum up, the following table is a summary of the number of pronouns and their percentages in Trump and Obama's speeches.

Table (22.) The frequency and percentage of personal pronouns used by Trump and Obama

\begin{tabular}{|l|c|c|c|c|}
\hline & \multicolumn{2}{|c|}{ Trump } & \multicolumn{2}{c|}{ Obama } \\
\hline & Frequency & Percentage & Frequency & Percentage \\
\hline $1^{\text {st }}$ person & 32 & $64 \%$ & 74 & $59 \%$ \\
\hline $2^{\text {nd }}$ person & 9 & $18 \%$ & 35 & $28 \%$ \\
\hline $3^{\text {rd }}$ person & 9 & $18 \%$ & 16 & $13 \%$ \\
\hline Total & 50 & $100 \%$ & 125 & $100 \%$ \\
\hline
\end{tabular}

The data in table 22 above emphasize the impression that Trump is trying to show his power and authority over the protesters. It also provides a sense of division as Trump in his use of the first-person pronoun whether singular or plural he Journal of Scientific Research in Arts (Language \& Literature) 5 (2021) 
distances himself from the people which is so disappointing to many Americans, and he shows his dominance as the president of America and as a member of his administration that will take an action to overcome this issue, while Obama is trying to express his compassion for the protesters as a former president and as a member of this community and as a black man.

\section{B. Ideational Meta-function}

According to Halliday's classification (2004, p.29), the following section presents the six processes of the transitivity system as found in the speeches of the two leaders.

\section{a. Transitivity in Trump's speeches}

By searching for verbs in the wordlist of Trump's speech using Sketch engine, it is found that there are 72 different verbs with 155 occurrences.

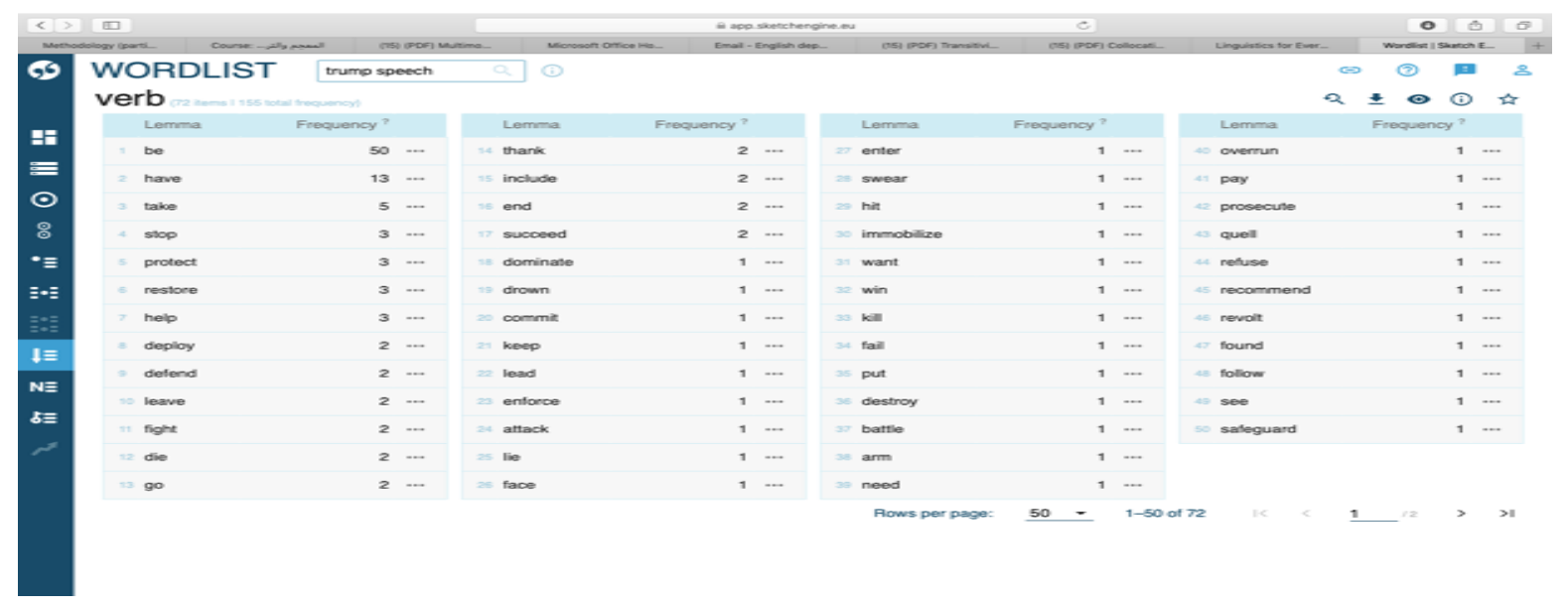

Fig. (2) The wordlist of verbs in Trump's speech

The following table provides the numbers and percentages of all the six processes used by Trump using the verbs in the wordlist.

Table (23) The six processes used by Trump

\begin{tabular}{|l|l|c|c|}
\hline Process type & Process verb & Number & Percentage \\
\hline $\begin{array}{l}\text { Material } \\
\text { Process }\end{array}$ & $\begin{array}{l}\text { Take- stop- protect -restore - keep - } \\
\text { put }- \text { go }- \text { die }- \text { fight }- \text { leave }- \text { defend } \\
- \text { deploy }- \text { help }- \text { battle }- \text { commit }-\end{array}$ & 53 & $75 \%$ \\
\hline
\end{tabular}




\begin{tabular}{|c|c|c|c|}
\hline & $\begin{array}{l}\text { face }- \text { prosecute }- \text { grip }- \text { succeed - } \\
\text { lead - enforce - arm - fail - enter - } \\
\text { overrun - immobilize }- \text { set }- \text { serve - } \\
\text { detain - attack - shoot - beat - do - } \\
\text { spill - vandalize - dispatch - win - } \\
\text { kill - hit - arrest - dominate - follow } \\
\text { - sicken - end - quell - safeguard - } \\
\text { battle - drown - found -destroy - lie } \\
\text { - threaten }\end{array}$ & & \\
\hline $\begin{array}{l}\text { Relational } \\
\text { Process }\end{array}$ & Be, have, include & 3 & $4 \%$ \\
\hline $\begin{array}{l}\text { Behavioral } \\
\text { Process }\end{array}$ & Need, want, revolt & 3 & $4 \%$ \\
\hline Mental Process & See, allow, uphold & 3 & $4 \%$ \\
\hline Verbal Process & $\begin{array}{l}\text { Thank, swear, speak, warn, } \\
\text { recommend, refuse }\end{array}$ & 6 & $8 \%$ \\
\hline $\begin{array}{l}\text { Existential } \\
\text { Process }\end{array}$ & $\mathrm{Be}$ & 1 & $2 \%$ \\
\hline Total & 155 & 72 & $100 \%$ \\
\hline
\end{tabular}

All the six process types exist in Trump's speech. The table shows that the material process is the highest of all with $53 \%$ followed by verbal process with $11 \%$ and each of the mental, relational and behavioral process with $4 \%$, and finally comes the existential process with $2 \%$. The following examples are taken from Trump's speech representing the different types of processes.

\section{1- Material Process Examples:}

a- I (actor) am also taking (material) swift and decisive action (goal) to protect (material) our great capital.

b- We (actor) will succeed (material). 


\section{2-Verbal Process Examples:}

a- I (sayer) swore (verbal) an oath (verbiage) to uphold the laws of our nation.

b-Thank (verbiage) you very much.

\section{3-Relational Process Examples:}

a- All Americans (token) are (identifying) rightly sickened (value) and revolted b-I (token) am (identifying) your President of law (value) and order

\section{4-Mental Process Examples:}

a- Small business owners (senser) have seen (mental) their dreams utterly destroyed.

b-But we (senser) cannot allow (mental) the righteous prize and peaceful protesters to be drowned out by an angry..

\section{5- Behavioral Process Examples:}

a- I (behaver) want (behavioral) the organizers of this terror to be on notice that you will face severe criminal ..

b- All Americans (behaver) are rightly sickened and revolted (behavioral) by the brutal death of George Floyd.

\section{6- Existential Process Examples:}

a- Where there is no justice, there is no liberty.

b- Where there is no safety, there is no future.

An analysis of the processes used by Trump reveals the heavy utilization of the material process which emphasize the actions planned by Trump. It demonstrates Journal of Scientific Research in Arts (Language \& Literature) 5 (2021) 
that they are all action process of intention. In all these clauses, Trump is trying to show how he is in control of his actions. He wants all protesters to know that he is taking steps to resolve this issue. Most of the examples show this material intentional actions in which Trump is the Actor and is in the initial position of the clause (subject) which is represented by the personal pronoun (I), while the goal is America or (you) referring to the protesters. All the verbs of this material process show Trump's power in ruling and governing the country. Another pattern that is identified in Trump's speech is the verbal process. The analysis of the verbal processes in Trump's speech reveals his positive attitude, as he thanks the protesters, swears and strongly recommends. The analysis also shows that the relational process comes in the third position and most of the examples that belong to this process are attributive relational process in which every part after the process explains the condition of what the senser felt or been.

\section{b. Transitivity in Obama's speech}

It is found that there are 135 different verbs in Obama's speech with 419 occurrences. The following screenshot is taken from the wordlist of verbs found in Obama's speech.

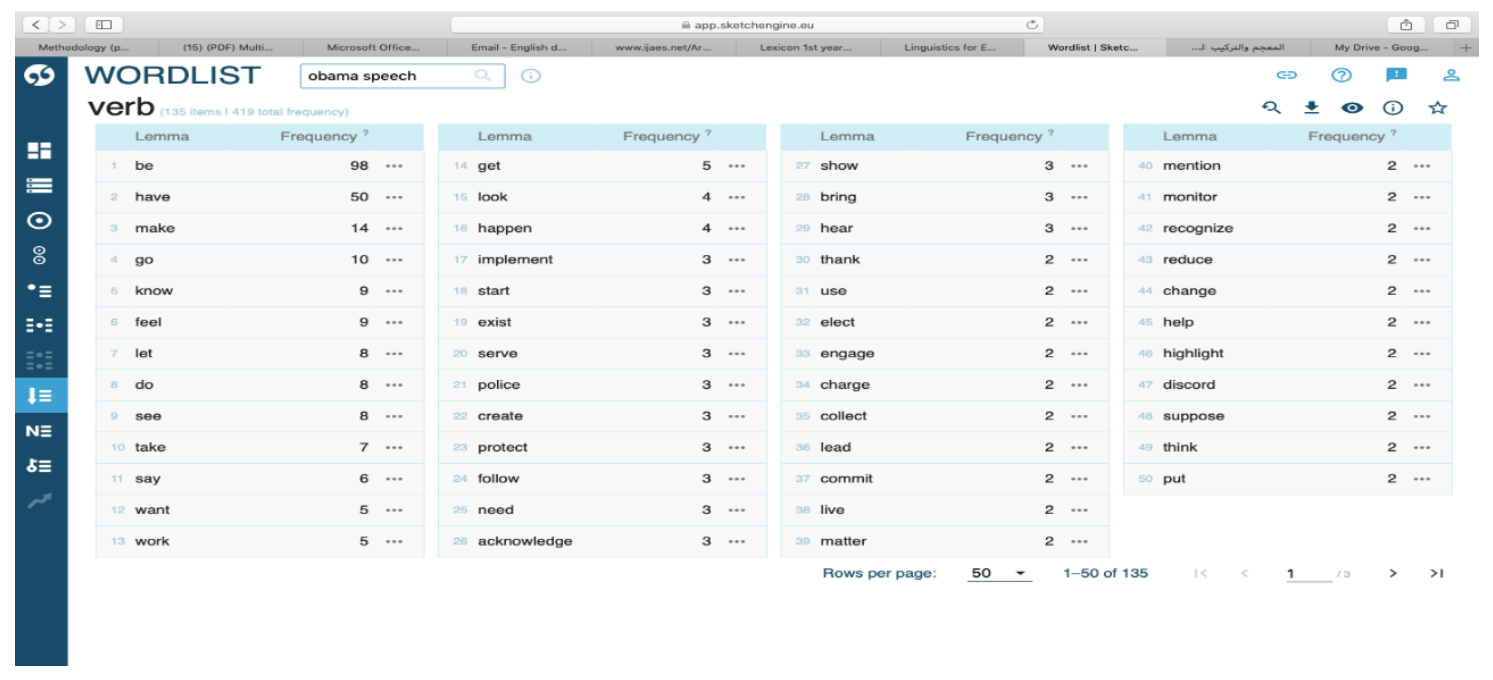

Fig. (3) A screenshot of the wordlist of verbs in Obama's speech

The following table provides the numbers and percentages of all the six processes used by Obama.

Table (24) The six processes used by Obama 
A Study on Obama's Optimistic Speech as Opposed to Trump's Disappointing Speech

from a Systemic Functional Grammar Perspective

\begin{tabular}{|c|c|c|c|}
\hline Process type & Process verb & Number & Percentage \\
\hline $\begin{array}{l}\text { Material } \\
\text { Process }\end{array}$ & $\begin{array}{l}\text { Commit, live, matter, monitor, } \\
\text { reduce, change, help, highlight, } \\
\text { discord, , put, base, increase, } \\
\text { investigate, distrust, justify, urge, } \\
\text { institionalize, dwindle, drive, make, } \\
\text { go, know, let, do, take, work, get, } \\
\text { happen, implement, start, serve, } \\
\text { create, protect, follow, show, bring, } \\
\text { use, elect, engage, collect, lead, } \\
\text { came, learn, march, expand, } \\
\text { communicate, begin, mobilize, } \\
\text { expose, experience, negotiate, find, } \\
\text { confront, motivate, move, offer, } \\
\text { outrage, present, promote, flourists, } \\
\text { protest, prove, build, affect, raise, } \\
\text { activate, redlin, demonstrate, guy, } \\
\text { deploy, cause, save, review, share, } \\
\text { showcase, deserve, describe, } \\
\text { awaken, stand, support, strength, } \\
\text { hold, tackle, develop, thrive, } \\
\text { identify, volunteer, add, close, } \\
\text { improve, display, train, throw, } \\
\text { underlie, translate, read, close, } \\
\text { precipitate, take place }\end{array}$ & 105 & $78 \%$ \\
\hline $\begin{array}{l}\text { Relational } \\
\text { Process }\end{array}$ & be , have, represent & 3 & $2 \%$ \\
\hline $\begin{array}{l}\text { Behavioral } \\
\text { Process }\end{array}$ & Be, want, need, require & 3 & $2 \%$ \\
\hline Mental Process & $\begin{array}{l}\text { Feel, see, look, hear, recognize, } \\
\text { think, listen, suppose, worry, forget, } \\
\text { remind, determine, hope, decide }\end{array}$ & 14 & $10 \%$ \\
\hline
\end{tabular}


A Study on Obama's Optimistic Speech as Opposed to Trump's Disappointing Speech from a Systemic Functional Grammar Perspective

\begin{tabular}{|l|l|c|c|}
\hline Verbal Process & $\begin{array}{l}\text { Say, think, mention, report, speak, } \\
\text { tell, acknowledge, thank }\end{array}$ & 8 & $6 \%$ \\
\hline $\begin{array}{l}\text { Existential } \\
\text { Process }\end{array}$ & Be, exist & 2 & $1 \%$ \\
\hline Total & & 135 & $100 \%$ \\
\hline
\end{tabular}

All the six process types exist in Obama's speech. The table shows that the material process is the highest of all with $77 \%$ followed by mental process with $10 \%$ and the verbal process represents $6 \%$, then come the relational and behavioural process with $2 \%$ and finally comes the existential process with $1 \%$. The following examples of clauses from Obama's speech representing the different types of processes.

\section{1- Material Process Examples:}

a- We (actor) implemented (material) some of these reforms (goal).

b- To bring about real changes, we both (actor) have to highlight (material) a problem (goal)..

\section{2- Mental Processes Examples:}

a- ...I (senser) just see (mental)what's happening with young people...

b-I (senser) see (mental) limitless potential that deserves to

\section{3- Verbal Processes Examples:}

a- I've heard some people (sayer) say (verbal) you have a pandemic.

b- And so I (sayer) just had to say (verbal), thank you (verbal) to them for helping to bring about this moment.

\section{4- Relational Processes Examples:}


a- our nation and the world (token) is (identifying) still in the midst of a global pandemic (value)

b-Cause you (token) 're (identifying) a vital part of the conversation (value)

\section{5-Behavioral Processes Examples:}

a- I (behaver) want (behavioral) you to know that you matter.

b-I (behaver) want (behavioral) to be part of the solution

\section{6- Existential Processes Examples:}

a- There is a change in mindset that's taking place.

b-The disparate impact that exists in our healthcare system.

The heavy utilization of the material process shows Obama's support to Floyd's protesters. An examination of the material processes reveals that they are all action process of support. He threw his support behind the efforts of peaceful protesters demanding police reforms. Moreover, he called on every mayor in the United States to review use-of-force policies. In all these clauses, Obama is trying to show his solidarity with the protesters. Most of the examples show this material support intention in which (Obama) is the Actor and is in the initial position of the clause (subject) which is represented by the personal pronoun (I) or (We) which shows his solidarity with the protesters, while the goal is America or (you) referring to the protesters. All the verbs of this process demonstrate his optimism in reforming the country. It also shows that the mental process comes in the second position showing that how optimistic Obama is as the reform effort could transcend political divisions. Obama's passions are running high, and this is clearly shown in the number of verbs that belong to the mental process such as see, hear and feel. Another pattern that is used by Obama is the verbal process. The analysis shows his positive attitude, as he thanks the protesters, and he is proud of them. Then, come two types of relational process; attributive and identifying processes. The behavioral process demonstrates that the behaver of the action tends to be Obama himself represented by the personal pronoun 'I' or Journal of Scientific Research in Arts (Language \& Literature) 5 (2021) 
'We' which includes Obama and the protesters. The last process and the least is the existential process. The following section is a comparison between the two speakers showing the differences between them and highlighting their ideologies.

Table (25) An overall transitivity results in Trump's and Obama's speech

\begin{tabular}{|l|c|c|}
\hline Process Type & Trump's speech & Obama's speech \\
\hline Material process & $75 \%$ & $78 \%$ \\
\hline Mental Process & $4 \%$ & $10 \%$ \\
\hline Relational Process & $4 \%$ & $2 \%$ \\
\hline Verbal Process & $8 \%$ & $6 \%$ \\
\hline Behavioral Process & $4 \%$ & $2 \%$ \\
\hline Existential Process & $2 \%$ & $1 \%$ \\
\hline
\end{tabular}

The overall transitivity analysis shows that both leaders use the six processes. Both tend to use material process in their speeches extensively, however, with different intentions. Whereas Trump, by using material process, shows the power of his actions, Obama's use of material process shows his support to the efforts of the peaceful protesters demanding police reforms. In order to enhance the results determined about the identity and the ideology of the two speakers, the following section is devoted to denotative and connotative semantic analysis of the lexical choices of both speakers.

\section{B. Denotative and Connotative Semantic analysis}

This section investigates the lexical choices of the two speakers to reveal the ideology of the speakers. By using Sketch engine tool, the analysis shows the five most frequently used nouns as well as examining the concordance tool to find out the connotations behind these words.

\section{Frequently used nouns in Trump's and Obama's speeches}

Table (26) The top frequent nouns used by Trump and Obama 


\begin{tabular}{|l|l|l|l|l|}
\hline & \multicolumn{1}{|c|}{ Trump } & Frequency & \multicolumn{1}{c|}{ Obama } & Frequency \\
\hline 1 & Law & 10 & People & 12 \\
\hline 2 & Action & 5 & Country & 12 \\
\hline 3 & Destruction & 4 & Community & 10 \\
\hline 4 & Violence & 4 & Police & 10 \\
\hline 5 & Country & 4 & Protest & 7 \\
\hline & Total & 214 & Total & 462 \\
\hline
\end{tabular}

The findings of this table show how Trump and Obama react to the current issue. On the one hand, it is found that 'law' is the most frequently used noun by Trump followed by 'action' and then 'destruction', 'violence' and 'country' are repeated with the same frequency. Trump gives more prominence to law to have control over the protesters to keep the country safe and secure without any chaos that could have happened by some protesters. On the other hand, in Obama's speech, what is noticeable is that 'people' and 'country' come in the first position followed by 'community' and 'police', and finally 'protest'. Thus, Obama's main concern is people, the black protesters, the Americans and the reform for a better future. To complete the investigation of the lexical choices used by the two speakers, the following section presents the denotative and connotative meanings of the top most frequent nouns used by them.

\section{a. Denotative and Connotative meanings of the nouns in Trump's speech}

\section{1- The lexical item 'law'}




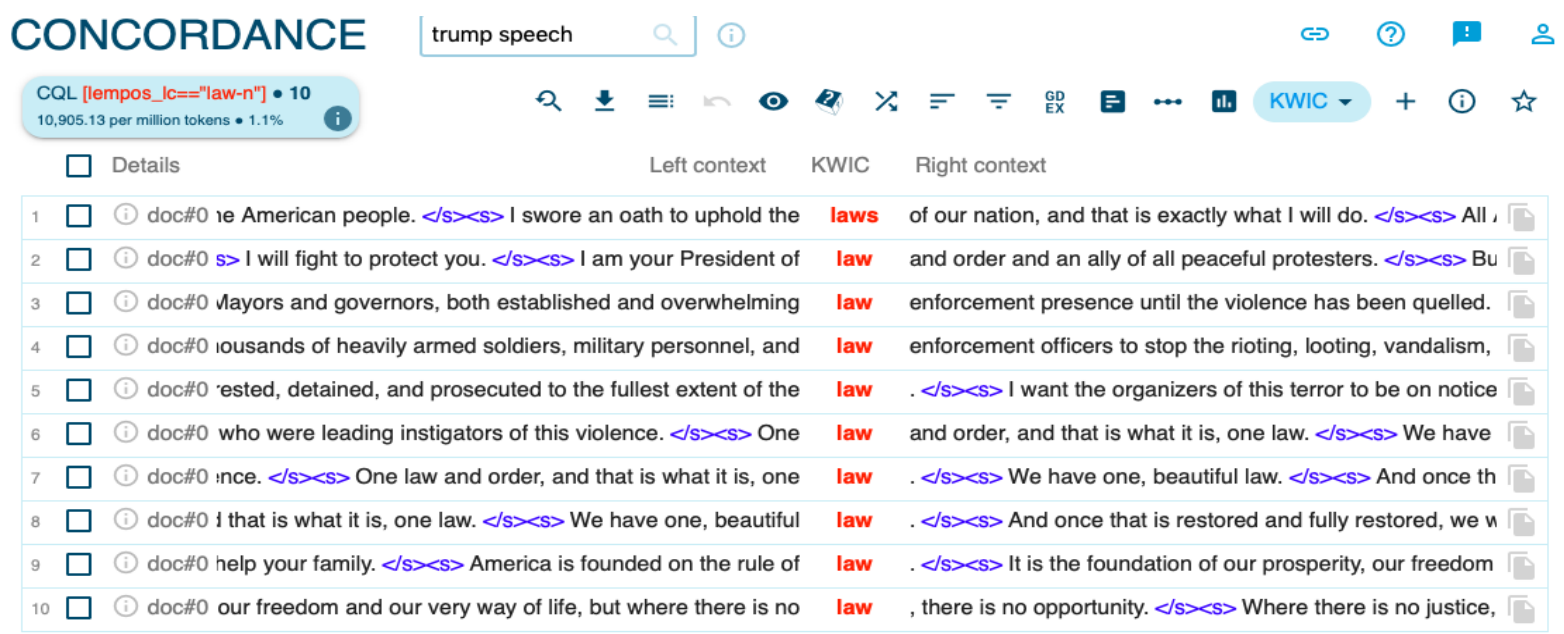

Fig. (4) The concordances of the word 'law'

The noun 'law' is used ten times by Trump. Law refers to the whole system of rules that everyone in a country or society must obey The frequent use of this word supports Trump's concern for keeping the country safe by law which is a norm of conduct for citizens. By repeating this word, Trump is sending a message to the protesters that law is made to provide guidelines and order upon the behavior of all the citizens and thus, the protesters should keep the country safe.

\section{2- The lexical item 'action':}

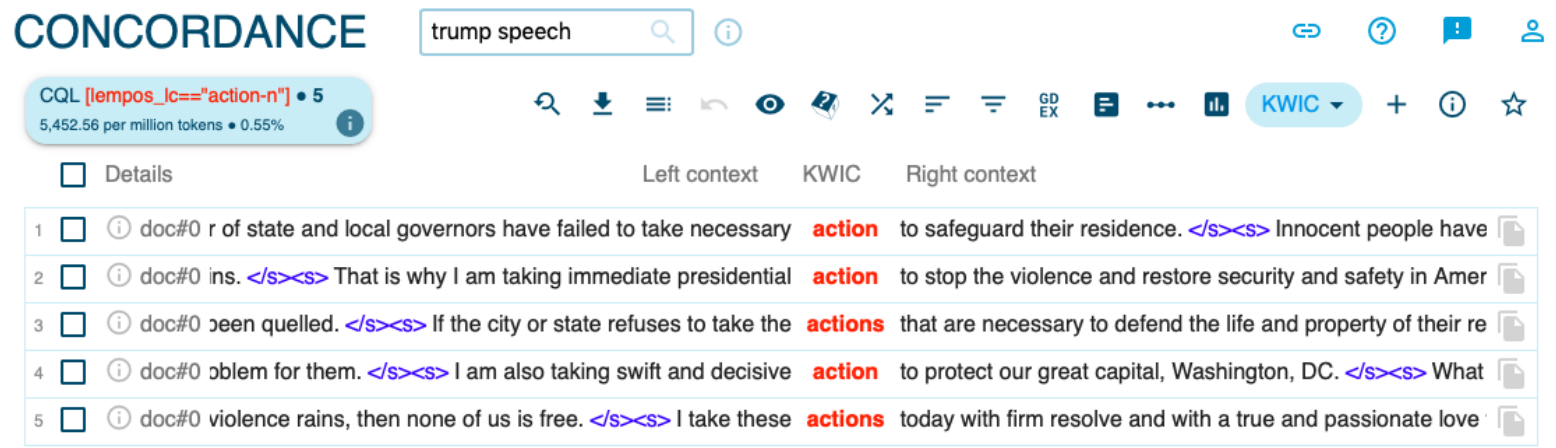

Fig. (5) The concordances of the word 'action'

The word 'Action' is repeated five times. Trump is the man of actions who can deal efficiently with the current matter, and this is reinforced by the words that are found with the word such as 'presidential action'. Moreover, Trump wants to show how strong he is and this is clearly shown from the adjective 'decisive' which occurs with the word 'action'. 


\section{3- The lexical items 'destruction', 'violence' and 'country'}

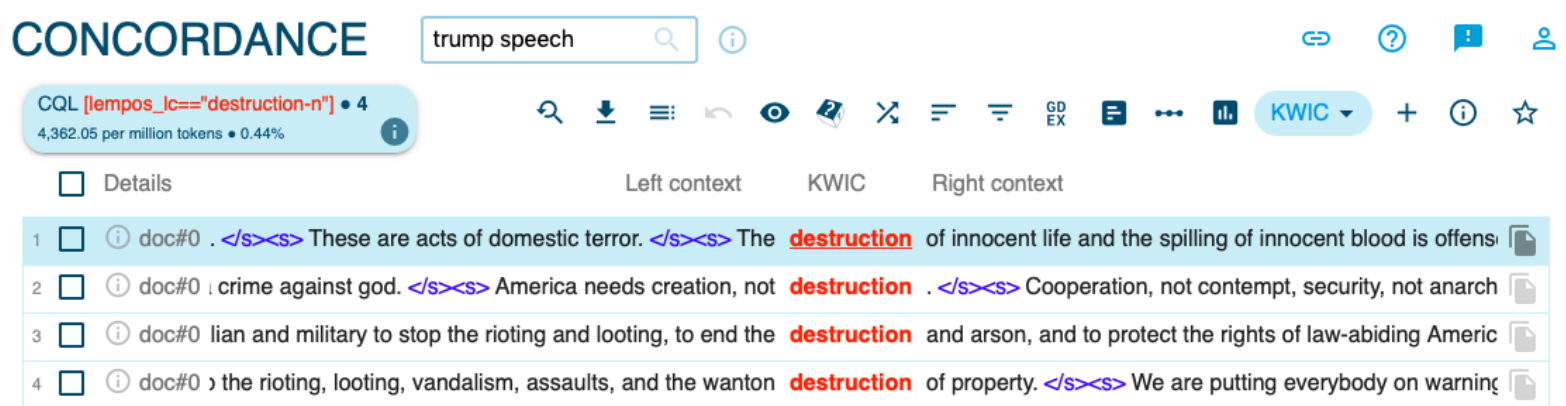

Fig. (6) The concordances of the word 'destruction'

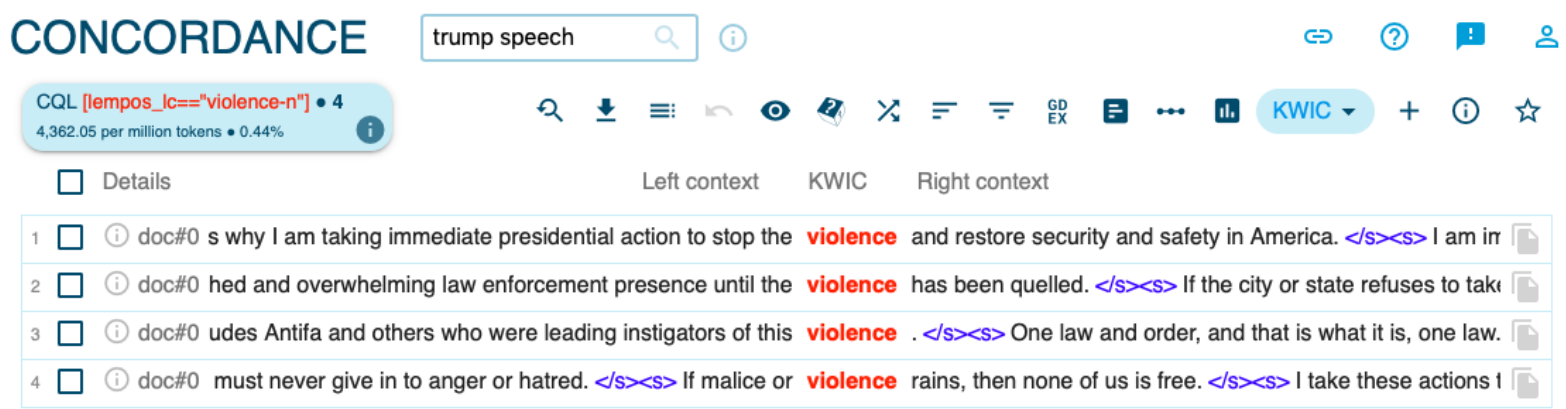

Fig. (7) The concordances of the word 'country

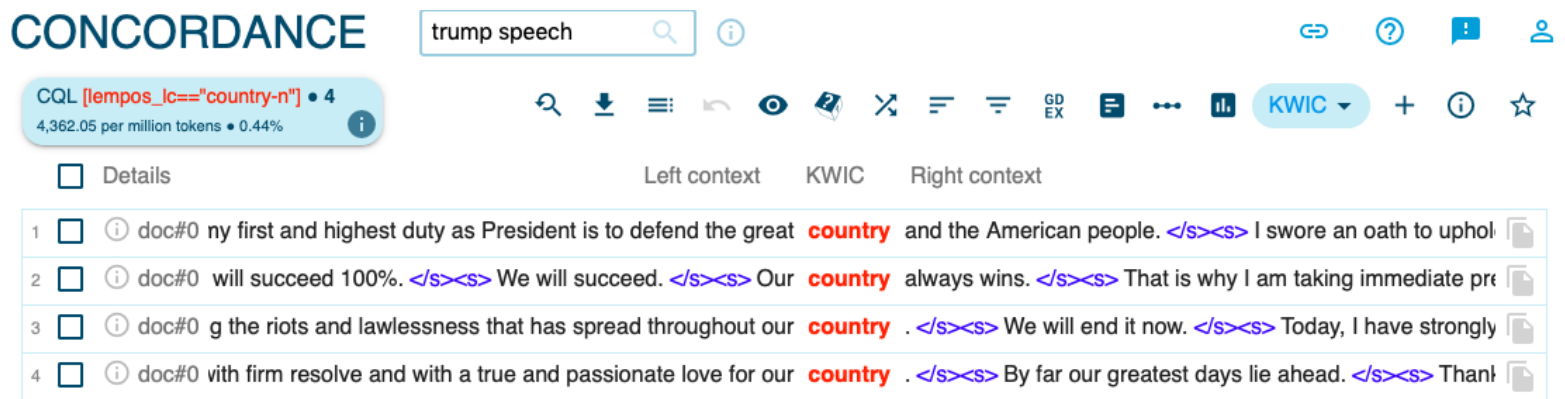

Fig. (8) The concordances of the word 'violence

Each of these nouns 'destruction, violence and country' is repeated four times by Trump. Using the word 'destruction' frequently after the word 'law' reinforces the idea that Trump is trying to deliver a message to the protesters that he is not going to allow any destruction to happen to his country. That is why the word 'destruction occurs with 'not'. He stresses the fact that America needs creation, 
not destruction. It also comes with the verb 'to end'. Trump wants to end any destruction that could affect America in any way.

The lexical item 'violence' is significant here. Mentioning destruction and violence in Trump's speech strengthens the idea that violence is prevented in America. There is a message of threat in Trump's speech and the repetition of these words reveals how Trump thinks. He thinks of how to retain peace and tranquility to his country. Therefore, the words that come with violence are the verbs 'to stop' and 'quelled'.

The fifth noun is 'country'. Trump tries to arose the protesters' feelings that is why he mentions the word 'country' accompanied by the possessive pronoun 'our', thus, he includes himself and the protesters. He wants them to be involved. Moreover, he uses positive words with the word country like the adjective 'great'. He always states that his 'country always wins' which shows how confident he is that the current issue will be resolved and everything will be under his control.

The semantic analysis of the frequently used words by Trump reveals his thoughts, thus providing his ideology which he kept emphasizing that he is the president of law and order. He didn't show concern about the protesters as much as his concern about law and his presidential actions. He spoke of violence and destruction, giving a message to the protesters that he will not accept any chaos to happen to the country. Finally, he describes his 'country' as a great country that will win. Thus, considering Trump's ideology concerning this crisis shows him as disappointing to many of the Americans.

b. Denotative and Connotative meanings of nouns in Obama's speech

\section{1- The lexical item 'people'}




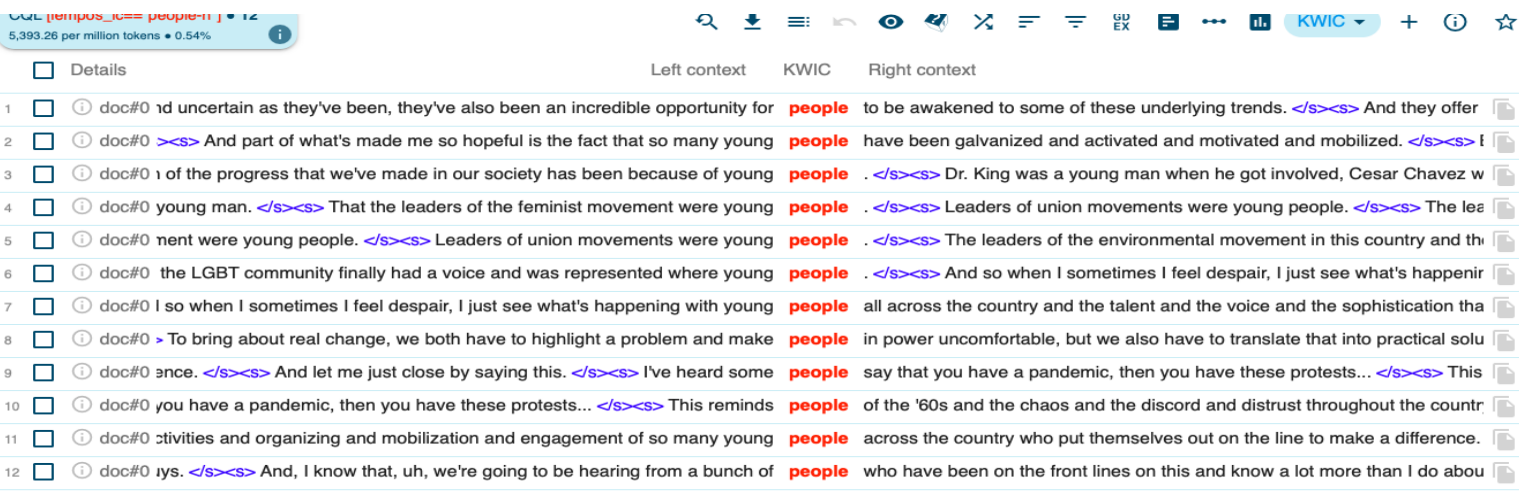

Fig. (9) The concordances of the word 'people'

The word 'people' refers to humans in general; everyone. However, in this study, Obama means different referents; the young protesters, leaders of union movement, leaders of the feminist movement, as well as the protesters of the 1960s and in other contexts he means the people of America. By checking the concordances of the word, it is found that the most frequently used word that comes with 'people' is the adjective 'young', thus it is obvious that he cares about the protesters especially the young black people, as much as he cares about the people of America in general. This shows that as America's first black president, he has faith in young people in the US and their power to change.

\section{2- The lexical item 'country'}

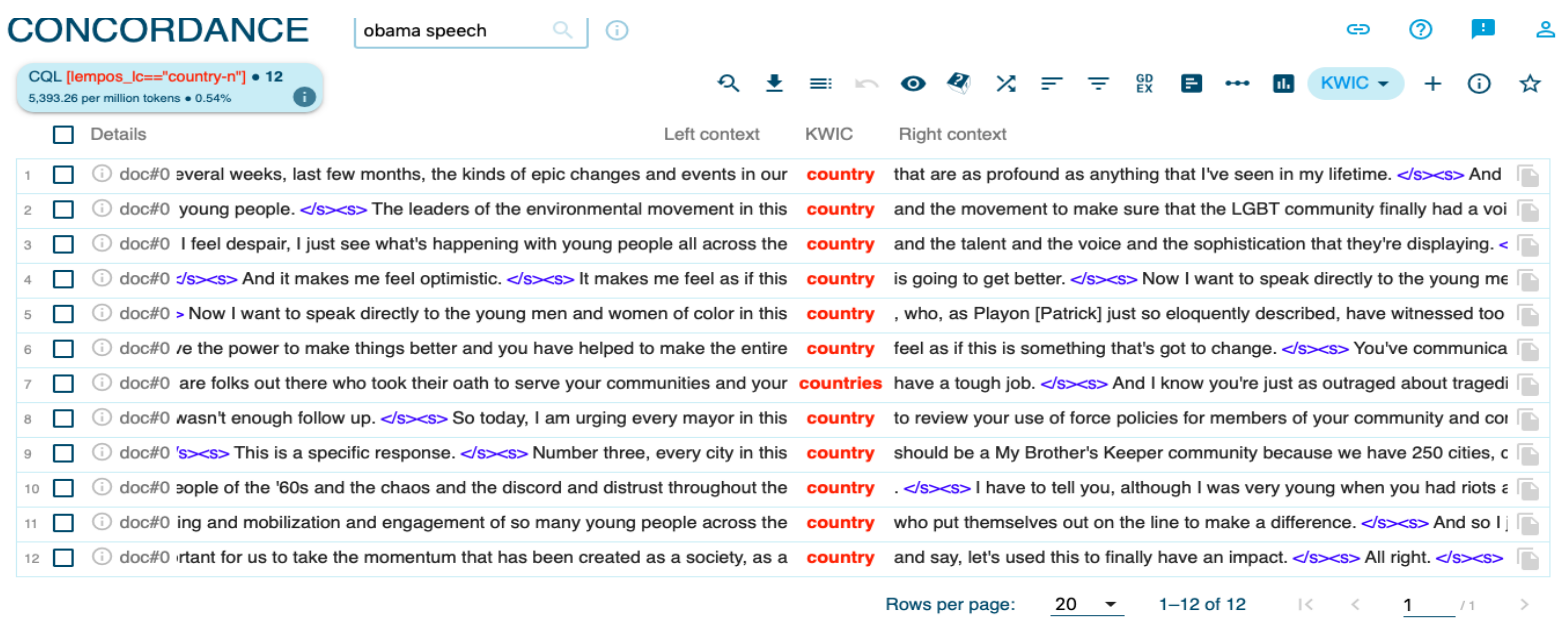

Fig. (10) The concordances of the word 'country' 
The word 'country', according to Obama's speech means America and he is all the time referring to America by 'this country'. Obama loves America and he feels that it is going to get better. Repeating the word 'country' several times shows his strong attachment to his homeland.

\section{3- The lexical item 'community'}

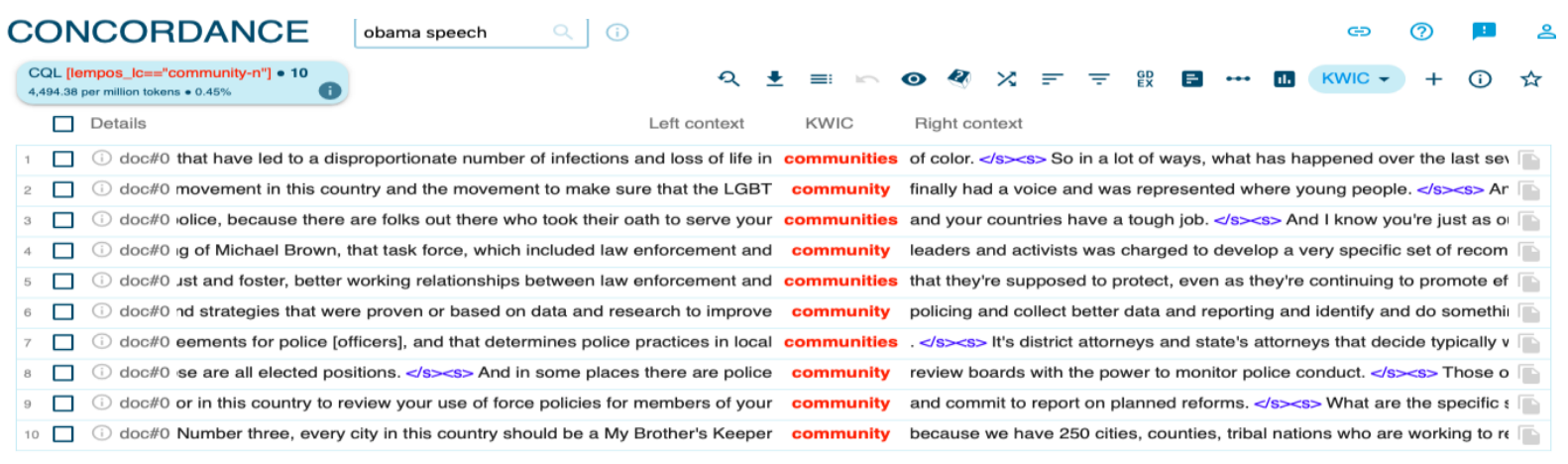

Fig. (11) The concordances of the word 'community'

The word 'community' means all the people who live in a particular area, country, etc. when talked about as a group. Obama uses the word 'community' to refer to American people in some contexts and to black people in other contexts.

\section{4- The lexical item 'police'}

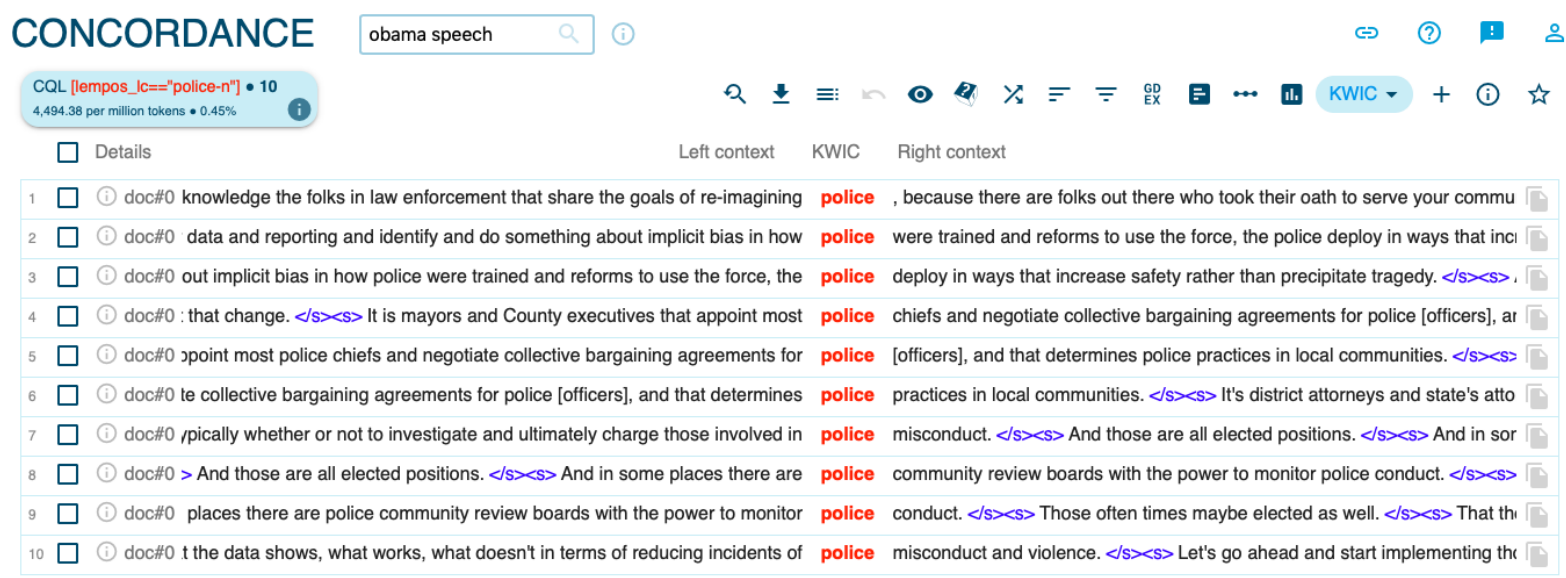

Fig. (12) The concordances of the word 'police'

The word 'police' is repeated by Obama several times to emphasize the role of the police to prevent and solve crimes, not to commit crime. The whole matter happens because of the racial attitude of some police officers which should be 
reformed to prevent such police violence. By looking at the concordances of the word, it is found that most of the words that come with 'police' are words such as misconduct and violence. Therefore, Obama criticizes police practices and their misconduct and violence.

\section{5- The lexical item 'protest'}

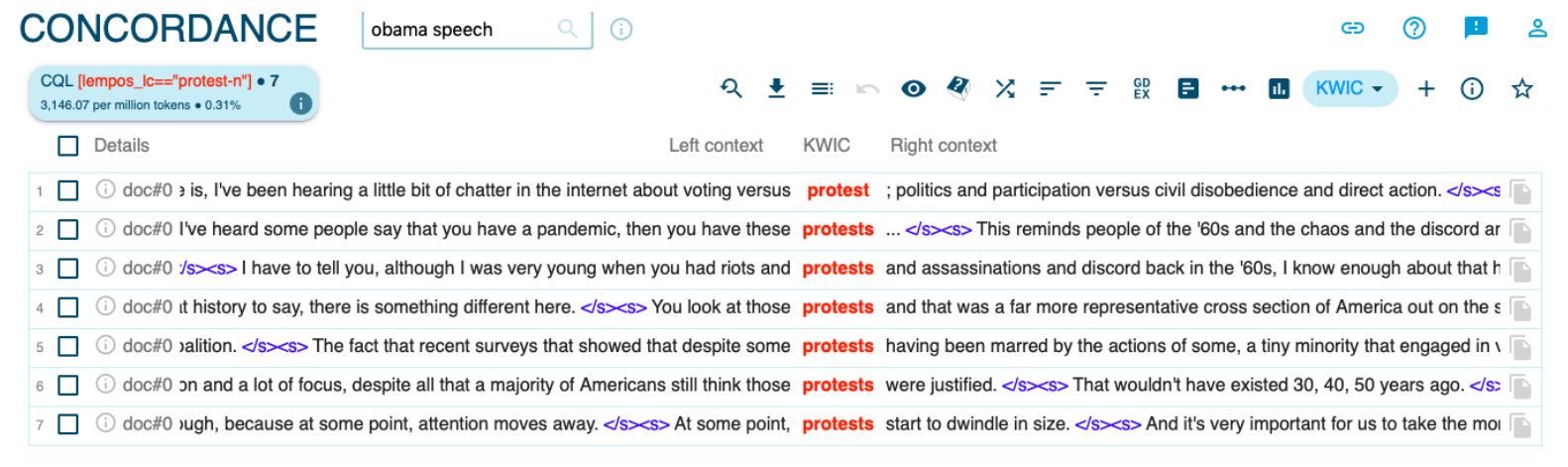

Fig. (13) The concordances of the word 'protests'

Obama mentions the word 'protest' several times and by checking the concordances of the word, it is found that most of the contexts in which the word is used refer to the protest positively and in spite of the tiny minority who were engaged in violence, yet the majority were justified and acceptable.

The semantic analysis of the top nouns used by Obama shows that he is a responsible man who cares about his country and people although he is not in a position to be able to solve the problem. He is an evocative and an excellent orator.

\section{Conclusion}

The study examines the speeches of Obama and Trump as a mode of reaction to an unusual event in the history of America about the death of George Floyd. The study was able to answer the questions proposed. As for question one, the analysis of the interpersonal metafunction through examining the mood, modality and pronoun system in Trump's speech and the ideational metafunctions through examining the transitivity system and the six processes, it is found that these were important tools that help in constructing the ideology of Trump, and accordingly in portraying his identity. The results show Trump's speech as disappointing to many of the Americans, and this is obviously perceived from his ideology and Journal of Scientific Research in Arts (Language \& Literature) 5 (2021) 
thoughts for his main concern is to show his power as the president of America who will not allow any violence or disorder to happen to this country rather than expressing any sympathy towards the death of Floyd. Morever, the results show his negative attitude towards the protesters and shows his assertiveness of being the president of America who will never allow any violence or chaos to happen in the country. Similarly, the analysis of the interpersonal and ideational metafunctions found in Obama's speech construct his thoughts and ideology and in turn helps to portray his identity. Obama seems to be a great public speaker and orator who cares about his country and this is clearly seen in his ideology and belief as his main concern is to show his anxiety about the protests and to send a message that he is supporting them and he cares about the future of America. The results also show his attitude towards America and this is expressed by his use of the question 'what can we do?' It also indicates his optimism towards the future and how to avoid such accidents in the future. Thus, the second question was answered.

The way politicians speak is considered part of their personality, therefore, it can be said that Trump's ideology and thoughts are significantly different from that of Obama's. All the time Trump is trying to give an impression of his authority and that he is in a position of power and control. His ideology gives also a voice that distances him from people. On the contrary, Obama wants people to feel that he is part of them. He shares their feelings and anger. He gives an impression of solidarity with the protesters and that he is involved in this issue and he will do his best to solve this issue though he is not in a position of authority. It also shows how Obama is optimistic and it shows his high passion. These highlights of the differences between the two leaders answered the third question.

To support these results, the semantic analysis of the most frequently used nouns indicates a lot about the character and identity of both leaders and their ideologies that were reflected through their lexical choices and their implications. In conclusion, these results about Trump and Obama's personality were in line with previous studies (e.g., Tinshe 2019, Suhadi and Baluqiah (2017)) that tackled the differences between the two leaders showing their different identities and ideologies. 


\section{References:}

Baker, Paul. (2006). Using Corpora in Discourse Analysis. London

Benwell, B., and Stokoe, E. (2006). Discourse and Identity. Edinburgh: Edinburgh University Press.

Biber, D. Conrad, S. Reppen, R. (1998). Corpus linguistics. Investigating language structure and use. Cambridge University Press.

Bloor, T., \&Bloor, M. (2007). The Functional Analysis of English. (2nd ed.). London: Edward Arnold

Bowcher, Werdy L., Fontaine, Lise and Schonthal, David. (2019). The Cambridge Handbook of Systemic Functional Linguistics. Cambridge University Press.

Charles W. Kreidler. (1998). Introducing English Semantic. London: Routledge.

Danijel, T. (2014). Corpus-based analysis of political speeches of warfare by Bush and Obama.

Emilia, E. (2014). Introduction Functional Grammar. Bandung: Pustaka Jaya.

Fairclough, N. (1989). Language and Power. London: Longman.

Fairclough, N. (1992). Language and Social Change. London: Polity Press

Fairclough, N. (1993). Discourse and Social Change. USA: Blackwell.

Finegan, Edward. 2004. Language. Its Structure and Use. 4 ed. United States of America: Thomson Wadsworth.

Gee, P. J. (2010). An introduction to discourse analysis: Theory and method. London: Routledge.

Goddard, Cliff and Wierzbicka, Anna. (2014). Words and Meanings. Oxford University Press

Halliday, M \& Matthiessen, C. (2004). An Introduction to Functional Grammar (3rd ed.). Oxford University Press

Halliday, M. A. K. (1978). Language as Social Semiotics. London: Edward Arnold.

Halliday, M. A. K. (1985). An Introduction to Functional Grammar. London: Arnold.

Halliday, M. A. K. (1994). An Introduction to Functional Grammar. London: Edward Arnold

Halliday, M.A.K \& Matthiessen, M.I.M. (2004). An introduction to functional grammar (3rd edition). London: Arnold. 
Halliday, M.A.K and Hasan, Ruqaiya. (1989). Language, Context and Text: Aspects of Language in a Social-Semiotic Perspectives. Oxford University Press

Halliday, M.A.K and Matthiessen, C. (2004). An Introduction to Functional Grammar. 2nd ed, London: Arnold

Halliday, M.A.K. (1994). An Introduction to Functional Grammar. 2nd Edition. London: Edward Arnold.

Halliday. M.A.K. (2014). Halliday's introduction to functional grammar. (Fourth edition), Routledge.

Leech, G. (1985). Semantics: the study of meaning. Harmondsworth: Penguine Books.

Lopez, Jorge \& de Alcala, Universidad. (2016). Ideolody, Identity \& Power: The Linguistic Construction of the Voice of the Other in Two Immigration Short Stories. Odisea, (pp. 119-138)

Mesthrie, R. (2010). "Critical Sociolinguistics Approaches to Language and Power". In F. Mesthrie, J. Swann, A.Deumert, \& W.L. Leap (Authors). Introducing Sociolinguistics (2nd ed.), pp.316-353). Edinburgh: Edinburgh University Press

Nguyen, Vi-Thong. (2018). A Comparative Analysis on Metaphoric Strategies in Presidential Inaugurals of Barack Obama and Donald Trump. Studies in Linguistics. Retrieved from http://dx.doi.org/10.17002/sil..48.201807.157

Ricardo, Pitarch. (2018). 'Mr. president, discourse matters: a contrastive analysis of Donald Trump and Barack Obama's discourse. Journal of Language Studies Semiotics and Semantics, 9 (1), pp.173-185. Retrieved from DOI: 10.22363/2313-2299-2018-9-1-173-185

Stubbs, M. (1983). Discourse analysis: The sociolinguistic analysis of natural language. Chicago: University of Chicago Press

Suhadi, A. \& Baluqiah, K. (2017). Donald Trump and Barak Obama inaugural address: Stylistic Analysis. Seminar on English Language and Teaching (ISELT-5), 169-177. 1 Retrieved from http://ejournal.unp.ac.id/index.php/selt/article/viewFile/8000/6103

Tinshe, Sonia and Junaida, J. (2019). "Who are Americans? Analysis of Obama and Trump's political speeches on immigration". A Journal of Culture, English Language and Teaching, Literature \& Linguistics. Vol.6, no.2. Retrieved from https://ejournal.umm.ac.id/index.php/celtic/article/view/9947 
A Study on Obama's Optimistic Speech as Opposed to Trump's Disappointing Speech from a Systemic Functional Grammar Perspective

Van Dijk, T.A. (1977). Coherence, Text and Context: Exploration in the Semantics and Pragmatics of Discourse. London: Longman

Van Dijk, T.A. (2006). Ideology and Discourse Analysis. Journal of Political Ideologies, 11 (2), (pp. 115-140)

Webster, Jonathan. (2003). On Language and Linguistics. In Bowcher, Werdy L., Fontaine, Lise and Schonthal, David. (2019). The Cambridge Handbook of Systemic Functional Linguistics. Cambridge University Press. 


\section{A Study on Obama's Optimistic Speech as Opposed to Trump's}

Disappointing Speech from a Systemic Functional Grammar Perspective

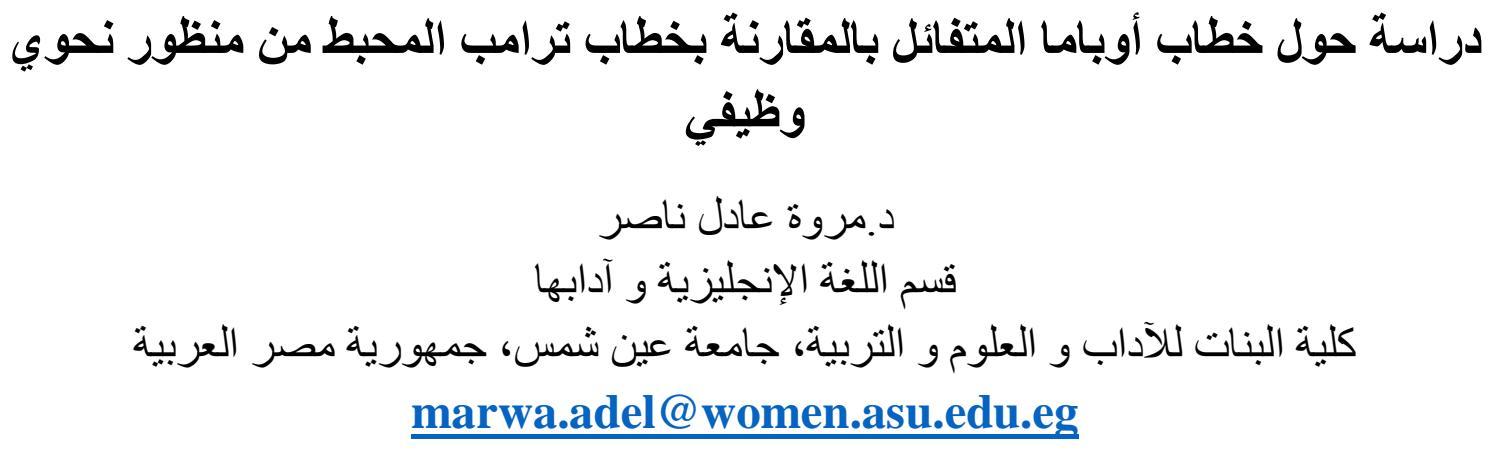

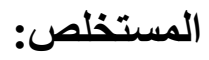

تقوم الدر اسة الحالية بتحليل خطابات تر امب و أوباما بشأن وفاة جورج فلويد. تبحث الدر اسة في مفهومين ؛ الهوية والأيديولوجيا كما هي موضحة من خلال الاختيار ات اللغوية للزعيمين. ولاستكثاف هوية

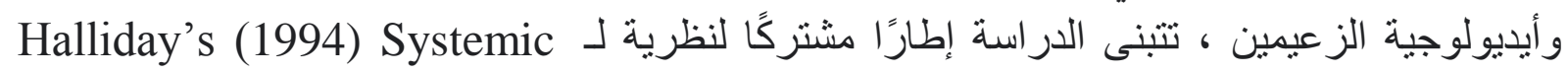
م ينم تحليل الخطابات Componential Analysis( 1910 . Functional Grammar and Leech’s التي تم جمعها من منظور معجمي نحوي ودلالي. أما بالنسبة للتحليل المعجمي يتم استكثاف الوظائف النحوية الفكرية من خلال در اسة نظام التعدد المستخدم من قبل المتحدثين. من ناحية أخرى، يبحث التهب التحليل الدلالي في الوظائف الثخصية كما تظهر في الخطابين من خلال العمليات الست التي اقترحها هاليداي. هذا بالإضافة إلى التحليل الدلالي التكويني للأسماء الأكثر استخدامًا. تتضمن المنهجية مزيجًا من الأساليب الكمية

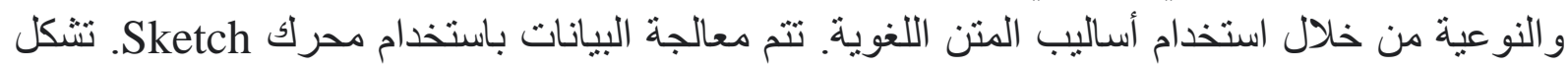

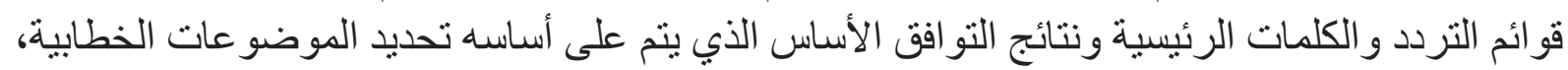

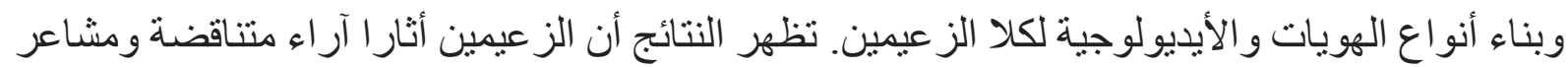
قوية.

الكلمات الدالة: تحليل خطاب، ايدولوجيا، هوية ،نظرية النحو الوظيفي، .خطابات سياسية 